\title{
Ecoturismo e Conservação na Área de Proteção Ambiental do Morro do Cachambi, Rio de Janeiro: pela tessitura das vozes geopoéticas em trilhas
}

\section{Ecotourism and conservations in the Ambiental Protected Area of Morro do Cachambi, Rio de Janeiro (Brazil): for the warp of geopoetics voices in the trails}

\author{
Lilaz Beatriz Monteiro Santos, Bruno Francisco Teixeira Simões; \\ Luiza Corral Martins de Oliveira Ponciano
}

\section{RESUMO:}

A Área de Proteção Ambiental do Morro do Cachambi (APAMC) está localizada no bairro Jardim Sulacap (JS), na Zona Oeste do Rio de Janeiro, e apresenta um grande potencial ecoturístico em sua face Norte, que foi reflorestada pelos moradores voluntariamente, por meio de um sistema de trilhas. No entanto, o bairro tem mudado sua relação com a APAMC, de continuação dos quintais além dos muros para um bloco verde, estático, preexistente e perigoso. Para conservar o Patrimônio Natural da APAMC é necessário fortalecer esta teia de relações entre os moradores do JS e o local, focando na reativação da visitação das trilhas. Desta maneira, foi desenvolvida uma pesquisa-ação junto com os moradores envolvidos na conservação das áreas verdes do JS, destacando as relações entre os seres humanos e o planeta Terra, numa abordagem Geopoética. Este trabalho apresenta o caminho percorrido desde os trabalhos de campo iniciais até a observação participante e a realização de seis eventos para público fechado (Caminhadas ecológicas) e três eventos para o público aberto (Trilhas guiadas), culminando no momento atual, de criação, instalação e apresentação de um novo produto, a Trilha Geopoética D.O.S.S.E.L. - Despertando Olhares Sensíveis Sustentáveis Ecológicos e Lúdicos -, que visa à integração dos seres humanos, Natureza, Arte e Tecnologia na APAMC. Treze instalações artísticas, chamadas de reservatórios de vidas geopoéticas ou GeoLiVes (Geopoetics Life Vessels) foram geradas por meio de uma (re)significação das impressões dos moradores do JS sobre a APAMC, a fim de fortalecer os fios materiais e imateriais que sustentam as iniciativas de ecoturismo e conservação que existem em todo o bairro, numa tessitura das vozes geopoéticas.

PALAVRAS CHAVE: Geopoética; Arte da Terra; Patrimônio Natural; APA do Morro do Cachambi; Parque Estadual da Pedra Branca. 
ABSTRACT: The Área de Proteção Ambiental do Morro do Cachambi (APAMC) is located at the Jardim Sulacap (JS) neighborhood, in the West Zone of Rio de Janeiro. It presents a pronounced ecotourism potential on its North side, which was reforested through a system of tracks by the residents, voluntarily. However, the neighborhood has changed its relationship with APAMC, from a continuation of backyards to a green, static, preexisting and dangerous place. The Natural Heritage of the APAMC needs to be conserved, by focusing on the reactivation of the visitation of the tracks, to strengthen this web of relationships between the residents of JS and their territory. Therefore, an action research was developed with the residents involved in the conservation of the green areas of JS, highlighting the connections between humans and the planet Earth, in Geopoetics approach. This work presents the path taken, from initial field work to participant observation and the six events for closed public (Ecological walks) and three events for the open public (Guided Trails), culminating in the present moment of creation, installation and presentation of a new product the Geopoetics Trail D.O.S.S.E.L. - Awakening Sensitive Sustainable Ecological and Playful Views, which aims the integration of human beings, Nature, Arts and Technology in the APAMC. Thirteen art installations, called GeoLiVes (Geopoetics Life Vessels) were generated by a (re)signification of the JS residents' impressions on APAMC, in order to strengthen the material and immaterial wires that sustains the Ecotourism and conservation initiatives in a tessitura of geopoetic voices.

KEYWORDS: Geopoetics; Landart; Natural Heritage; APA do Morro do Cachambi; Parque Estadual da Pedra Branca.

\section{Introdução}

O Ecoturismo é um segmento do turismo que utiliza de forma sustentável o Patrimônio Natural, sendo baseado na conservação e na conscientização ambiental, assim como no desenvolvimento local. Ele apresenta grande potencial para gerar benefícios econômicos e educativos, além de minimizar os impactos ambientais e socioculturais do uso dos espaços pelos visitantes (EMBRATUR, 1994; WEARING; NEIL, 2014). Desta forma, iniciativas de ecoturismo ao redor do mundo tentam estabelecer uma relação entre o fenômeno turístico, a cultural local e a educação ambiental, como um mecanismo de valorização do Patrimônio Natural (UNESCO, 1972), utilizando o turismo como parte de uma dinâmica de conservação, na qual visitantes e residentes são atores interativos no processo de valorização do Patrimônio Natural e dos serviços ecossistêmicos associados ao mesmo.

As vivências de Ecoturismo promovem uma apreensão do local como patrimônio daquela comunidade, o que é facilitado por meio de uma abordagem sob o enfoque do Patrimônio integral. A ascensão das iniciativas de Ecoturismo num cenário mundial, onde a conservação dos ecossistemas tem sido amplamente discutida, evidencia a necessidade de refletirmos sobre uma nova forma de habitar o mundo. Se o "meio ambiente" não for preservado e mantido em toda sua complexidade, a existência, em breve, não terá mais base, a cultura não terá mais fundamento, e as práticas individuais, mais nenhum sentido (TUAN, 2012; BOUVET, 2012; WHITE, 2014).

A realização de projetos de Ecoturismo em locais fora das Unidades de Conservação (UCs) ou inseridos em UCs de uso sustentável permite a conectividade entre as áreas, promovendo a manutenção de processos ecológicos essenciais para 
a perpetuação das populações e comunidades em longo prazo (PRIMACK; RODRIGUES, 2001). Nosso local de estudo, a Área de Proteção Ambiental do Morro do Cachambi (APAMC) (lei Municipal № 4.659/2007) está localizada no bairro Jardim Sulacap (JS), Zona Oeste do Rio de Janeiro. Apesar da pequena porção de Mata Atlântica remanescente, a APAMC é uma parte relevante do Parque Estadual da Pedra Branca (PEPB), pois representa a sua zona de amortecimento e a conexão desta região com o Parque Nacional da Tijuca pelo caminho proposto pelo projeto Mosaico Carioca, que inclui o Corredor Verde e tangencia a trilha TransCarioca em seu trecho 9 (Estrada dos Teixeiras X Aqueduto do Catonho) (SMMA, 2015).

Jardim Sulacap é um bairro planejado, de acordo com o modelo urbano de cidade jardim criado pela Cia. Sul América Capitalização em 1945, sendo predominantemente residencial e de classe média (IBGE, 2010). Atualmente ele é conhecido como um bairro verde, com 16 praças e ruas arborizadas, sendo cercado por um cordão verde de morros (Valqueire, Cachambi e Caixa de água) (SANTOS; PONCIANO, 2019). Neste contexto, destacamos a relevância da APAMC, contemplada por uma iniciativa voluntária de reflorestamento pelos moradores, que para acessar a área traçaram um sistema de trilhas. Esta APA abrange aproximadamente 10 hectares na face Norte do MC, e tem sido reflorestada desde 1997. O fundador desta primeira iniciativa, Sr. Eduardo Carvalho, promoveu diversos mutirões de plantio e caminhadas ecológicas, recuperando este ambiente junto com outros moradores. Segundo os registros dos voluntários, em 2007 já ocorriam trilhas guiadas, cujo objetivo principal era o reflorestamento, inclusive com grupos escolares. Este movimento dos moradores culminou na criação da APA do Morro do Cachambi (APAMC) em 2007.

Uma característica importante da comunidade do bairro JS é o perfil ativista na conservação do Patrimônio Natural. O reflorestamento continua sendo realizado pelos moradores e esta área já foi contemplada por algumas ações do governo, como o projeto Mutirão Reflorestamento (SANTOS et al., 1987). Apesar da APAMC ter sido frequentemente utilizada pela comunidade do JS, por meio de diversas trilhas e o desenvolvimento de práticas esportivas, ainda não há um acompanhamento dos impactos ambientais destas atividades. Além disso, o uso destas áreas diminuiu drasticamente nos últimos anos por diversas questões, como o difícil acesso à APAMC (o principal acesso está localizado no fundo das casas da Rua Euzébio de Almeida) e a falta de eventos guiados, uma vez que a partir de 2014, devido ao falecimento do Sr. Eduardo Carvalho, os eventos organizados pelos moradores tinham sido encerrados.

Os voluntários continuaram atuando na manutenção da área reflorestada, apesar da redução do número de moradores ativos nas iniciativas e outros fatores limitantes, como a seca das nascentes que eram utilizadas para o sistema de irrigação, o regime de chuvas e as queimadas. Outro motivo que distanciou os moradores da APAMC foi a sensação de insegurança, pois o Morro do Cachambi é cercado por serras ocupadas por invasões atualmente sob o domínio de traficantes de drogas e milícias (como o Jordão, na Praça Seca - na direção Oeste e a Nogueira de Sá, ao Sul). O próprio site da TransCarioca não recomenda a utilização do trecho 9, devido aos episódios recorrentes de insegurança. Apesar disso, JS ainda não apresenta comunidades em seu território, o que pode ser associado com a origem planejada do bairro e com a militância dos moradores pela conservação das áreas verdes do entorno. 
Desde a realização das primeiras ações de reflorestamento e educação ambiental foram promovidas diversas correlações afetivas dos moradores com a APA, que são sustentadas pela existência daquele ecossistema. Na medida em que as ações da década de 1990 resultaram no aumento do dossel daquele fragmento florestal, os serviços ecossistêmicos foram sendo diversificados, promovendo uma maior participação dos moradores nas ações relacionadas com a APA. A força motriz deste processo foi a memória do bairro, que fomentou o perfil ativista nos moradores. Deste modo, nota-se como a recuperação ambiental da APAMC está fortemente vinculada com a relação afetiva dos moradores do JS, evidenciando uma riqueza de serviços ecossistêmicos culturais (MEA, 2005), como as caminhadas ecológicas e os mutirões de reflorestamento, que podem ser classificados dentro da subcategoria recreação e ecoturismo (uma vez que estas atividades visam minimizar os impactos ambientais e promover benefícios para os moradores). Ainda que sejam atividades voluntárias, elas geram lazer, melhoram a qualidade do ar, deixam o clima mais ameno e servem de barreira sonora, além dos benefícios econômicos indiretos decorrentes da sua visitação, movimentando o bairro e consequentemente seus estabelecimentos comerciais. Outro benefício é a própria ocupação dos espaços por grupos de moradores, promovendo uma sensação de segurança (EMBRATUR, 2004; MILLENNIUM ECOSYSTEM ASSESSMENT, 2005; WEARING; NEIL, 2014).

Desta forma, entende-se que conservar a APAMC abrange ações mais amplas que apenas a continuidade do reflorestamento, incluindo a manutenção e valorização de seus serviços ecossistêmicos, sobretudo os culturais. Para tal, é necessário expandir a área de abrangência destas ações, incluindo o entorno, pois o perfil ativista do bairro JS também compõe este ambiente. Segundo Uexküll (1921, apud KRUSE, 2005), o ambiente está sempre relacionado à percepção de um organismo, e isto corresponde à estrutura e ao estado de seu "mundo interno". O entorno é subjetivamente significativo, por um conjunto de experiências de um indivíduo ou grupo, o que o autor intitulou de "umwelt", abrangendo nestas experiências tanto os impactos percebidos abertamente (e sensorialmente), quanto as influências mais sutis/subconscientes, como a pressão atmosférica. Ou seja, o ambiente pode ser compreendido como uma teia de organismos, atrelada a um território e composta por elementos bióticos e abióticos, incluindo os seus serviços ecossistêmicos.

Ressalta-se que a existência desta teia é independente do grau de consciência dos seres envolvidos na mesma, e ainda que a sensibilização quanto à importância da conservação da Natureza esteja sendo desenvolvida a partir de um Patrimônio Natural específico (APAMC) seus efeitos podem ser compartilhados com as áreas naturais no geral. Numa escala local, a sensibilização pode promover a conservação da APAMC por meio da perpetuação das memórias atreladas a ela, e consequentemente, das relações e ações que a conservaram nas últimas décadas. Para tal, a Geopoética foi selecionada como fio condutor do embasamento teórico deste trabalho, abrangendo a análise das relações entre os seres humanos, Natureza, Arte e Tecnologia, numa tessitura dessas vozes geopoéticas.

Em sua vertente mais abrangente, a Geopoética está associada não apenas com as representações literárias das paisagens naturais e culturais, forma como aparece em trabalhos associados com a Geografia e Literatura, mas inclui igualmente as diversas formas de relação dos seres humanos com o planeta Terra. Esta definição mais ampla está de acordo com a linha de pensamento desenvolvida 
por Kenneth White, fundador do Instituto Internacional de Geopoética (WHITE, 1998).

No contexto atual a Geopoética torna-se ainda mais interessante como ferramenta para estimular a conservação da Natureza, por oferecer um terreno de encontros e estímulos recíprocos entre a Biologia, Geociências, Poesia, Arte, Filosofia, Física, Química e outras disciplinas, desde o momento em que as pessoas que trabalham com estas áreas estejam prontas para saírem dos seus espaços isolados e se encontrarem em ambientes inusitados, numa busca por novas relações e pontos de contato das Arte com as Ciências (PONCIANO, 2018).

Outro campo que também pode ser correlacionado com esta proposta interdisciplinar é a "Land Art" ou "Earth Art", traduzida como Arte da Terra ou Arte Ambiental. Nesta corrente, o terreno natural, em vez de apenas constituir um ambiente para uma obra de arte, se torna o próprio objeto, trabalhado de modo a integrar-se na obra (LAILACH, 2007). A Arte da Terra também foi associada com sistemas híbridos, no qual sistemas mecânicos e eletrônicos fundem-se não apenas fisicamente, mas também esteticamente, proporcionando formas inovadoras de perceber e expressar a realidade (HAMDAN, 2015; NÓBREGA; FRAGOSO, 2015).

A nossa percepção é diretamente relacionada ao ecossistema em que está inserida e aos seus fenômenos, uma vez que é um produto da relação com o mundo. A percepção de um espaço em que elementos orgânicos e inorgânicos coexistem e podem interagir pode ser tanto aquilo que é percebido por meio de estímulos sensoriais quanto de informações digitais, interpretadas pelo nosso cérebro com ou sem o auxílio de uma máquina. Desta forma, as hibridações da Arte, integrando elementos bióticos, abióticos e virtuais, também podem ser exploradas dentro do campo de estudo da Geopoética.

Neste contexto de pesquisa transdisciplinar, será apresentado o caminho trilhado por toda a equipe que participou deste projeto junto com os moradores do JS para desenvolver uma trilha geopoética na APAMC. A proposta é que esta trilha represente a complexa teia de relações que conecta as várias partes dos sistemas da Terra, onde as intervenções feitas no ambiente são componentes projetados para despertar o olhar do visitante quanto aos múltiplos papéis dos seres humanos em relação à conservação da Natureza.

\section{Objetivo}

Promover a conservação do Patrimônio Natural da APA do Morro do Cachambi por meio do Ecoturismo e da Geopoética, focando na reativação da visitação das trilhas traçadas pelos moradores do Jardim Sulacap.

\section{Metodologia}

Neste estudo foi utilizado o método de pesquisa-ação, devido ao contexto e o objeto de pesquisa, pois uma das autoras é moradora de JS e participou desde a infância das iniciativas voluntárias de reflorestamento da APAMC. Entende-se por pesquisa-ação uma estrutura de relação entre os pesquisadores e as pessoas envolvidas no estudo da realidade do tipo participativo/coletivo (BALDISSERA, 2001), diferindo de outros autores que restringem a concepção de seu uso a uma orientação de ação junto a grupos que pertencem à classes sociais populares. Foram reunidos diversos métodos para promover uma ampla e explícita interação 
entre as pesquisadoras e as pessoas envolvidas na conservação do Patrimônio Natural local (THIOLLENT, 2008), possibilitando uma construção em conjunto com os moradores que já estavam envolvidos na conservação das áreas verdes do JS. Esta interação foi possibilitada pela espiral de etapas que compõem o método da pesquisa-ação; em ciclos de planejamento, ação e descobertas resultantes dessa ação, iniciada pelo levantamento bibliográfico efetuado a partir de uma visão holística do Patrimônio Natural, que incluiu os dados históricos, culturais, a biodiversidade e a geodiversidade da região do bairro JS, enfocando a APAMC.

A investigação sobre as relações dos moradores com os projetos envolvidos na conservação das áreas verdes do bairro JS (Figura 1) e os serviços ecossistêmicos culturais atrelados a elas (APAMC e as praças do JS) foi feita por meio da observação participante. As iniciativas acompanhadas foram 0 reflorestamento da APAMC por ação voluntária dos moradores (que ocorre desde 1997), a Horta Comunitária da Praça Quincas Borba (QB) e a AMISUL (associação de Moradores e Amigos de Sulacap), abrangendo atividades administrativas (reuniões e debates), educativas (caminhadas, trilhas guiadas, oficinas e palestras), e recreativas (eventos e festas de bairro), participando de forma ativa nestes encontros e registrando-os por meio de filmagens que foram analisadas de duas formas (os momentos em grupo, por descrição, e os momentos de conversa envolvendo de um a três moradores, por transcrição das falas). A importância dessa técnica reside no fato de podermos captar uma variedade de situações ou fenômenos que não são obtidos por meio de perguntas, uma vez que quando observados diretamente na própria realidade, transmitem o que há de mais imponderável e evasivo na vida real (MINAYO, 2010).

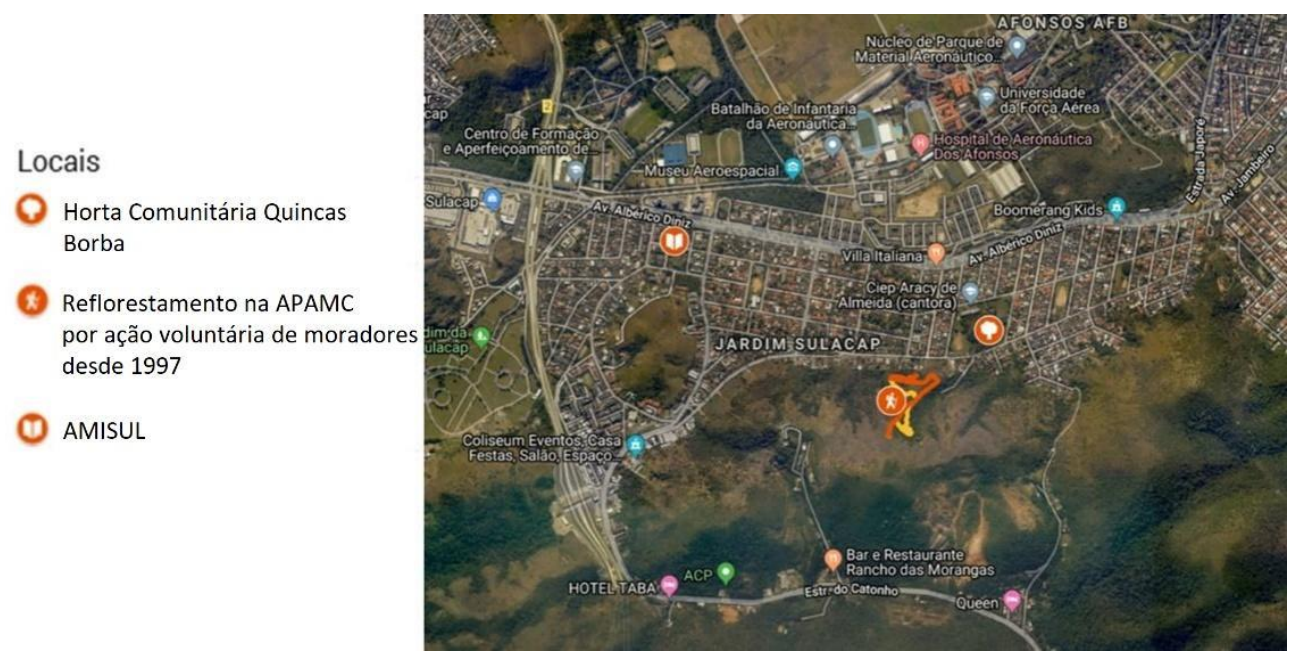

Figura 1: Mapa do bairro JS, evidenciando com o símbolo de um livro a associação de moradores, com uma árvore a horta comunitária Quincas Borba e com uma pessoa caminhando o local das trilhas no reflorestamento na APAMC por ação voluntária de moradores desde 1997. Fonte: Googlemaps.

Figure 1: Map of JS neighborhood, showing with the symbol of a book the residents' association book, a tree in the Quincas Borba community garden and a person walking the location of the trails in the APAMC reforestation area of APAMC by voluntary action of the residents since 1997. Source: Googlemaps.

Concomitantemente, desde agosto de 2017 foram realizados trabalhos de campo semanais ao longo da área reflorestada na APAMC. Tais dados foram utilizados para embasar a reestruturação das trilhas utilizadas pelos moradores, o 
mapeamento de áreas de risco a serem evitadas pelo seu estado de manutenção ou fragilidade, e os pontos estratégicos da trilha selecionada para a criação do novo produto, de onde germinaram as instalações artísticas que compõe a trilha Geopoética D.O.S.S.E.L. Completando este processo de reativação da visitação das trilhas foram realizados ensaios (eventos nos moldes utilizados pela iniciativa voluntária dos moradores), utilizando o acesso à APAMC pelos fundos da casa da família do fundador do projeto de reflorestamento - a "sede".

Com os dados obtidos pelas etapas citadas acima, foi feita uma análise e triangulação dos mesmos (MINAYO, 2010) para a criação da trilha geopoética D.O.S.S.E.L. - Despertando Olhares Sensíveis Sustentáveis Ecológicos e Lúdicos -, que visa a integração dos seres humanos, Natureza, Arte e Tecnologia na APAMC. A trilha geopoética é composta por uma obra de arte - TEIA DOSSEL (resultante da união de instalações artísticas distribuídas por treze pontos da trilha), três atividades de sensibilização (articulando os sentidos, plantio de mudas nativas da Mata Atlântica e lanche solidário) e três métodos avaliativos (questionário pareado por indivíduo, gravação de áudio e imagem, e roda de conversa) resultantes de uma (re)significação das impressões dos moradores do JS sobre a APAMC, a fim de fortalecer os fios materiais e imateriais que sustentam as iniciativas de ecoturismo e conservação que existem em todo o bairro

\section{Resultados}

Apresentamos aqui os resultados obtidos por meio da escuta das vozes geopoéticas nas "trilhas" que nos levaram a viajar por um sinuoso percurso que abarcou treze eventos no período de setembro de 2017 a outubro de 2018. Entre os eventos organizados pela presente pesquisa, foram realizadas seis caminhadas ecológicas na APAMC - com público fechado (apenas para moradores do JS) e três trilhas guiadas (para público aberto, incluindo a aplicação dos questionários para a pesquisa de opinião). Já quanto aos eventos organizados em parceria com outros projetos do JS, participamos de duas festas da primavera na Horta Comunitária QB, um encontro de voluntários e seus familiares nas trilhas da APAMC, e o lançamento do documentário intitulado "Jardim Sulacap: primeiro projeto de moradias populares do Brasil". Além destes eventos, mais de 50 outros encontros semanais foram organizados na APAMC por motivos diversos (manutenção da trilha, plantio de mudas, rodas de conversa), e a nossa participação em reuniões de moradores na AMISUL. $O$ relato e a discussão destas atividades seguem abaixo, em ordem cronológica, como forma de demonstrar o caminho percorrido por esta pesquisaação, que começou no "berço" e se expandiu pelo "tronco" até chegar ao momento atual de florescer no "dossel" da Geopoética na APAMC, culminando na criação de um novo produto, a trilha geopoética D.O.S.S.E.L.

\section{O "berço" da Geopoética}

O marco de início desta jornada na APAMC - o "berço" da Geopoética começou no dia 16 de setembro de 2017, quando foi possível acompanhar uma trilha organizada por um morador que atua no reflorestamento voluntário da APAMC, junto com seus familiares e amigos - um segundo voluntário, oito crianças (até 12 anos), três jovens adultos ( 18 a 25 anos) e cinco adultos (25 a 60 anos). Ao longo do percurso os voluntários narraram as histórias das árvores e quem as plantou, entrelaçando estas informações com a história do projeto iniciado pelo Sr. Eduardo 
Carvalho, em 1997. A forma com que os voluntários guiaram este grupo foi semelhante à das caminhadas ecológicas, que ocorreram no local até 2014.

Após este evento iniciou-se um movimento para reativar as caminhadas ecológicas, como forma de atrair os antigos voluntários para retomar 0 reflorestamento e reatar os laços, estendendo-os até a nova geração de moradores, a fim de perpetuar os cuidados com a APAMC. Entretanto, havia um receio dos moradores mais antigos que voltaram a atuar na APAMC sobre a responsabilidade de receber visitantes de outros bairros no local, e principalmente o perigo de atrair outros interesses que não seriam benéficos para aquela área. Jardim Sulacap é um dos dois únicos bairros do Rio de Janeiro que não tem comunidades, então era alarmante o medo de uma invasão no local, neste momento em que os moradores estão menos envolvidos na conservação da APAMC.

Neste mesmo período (de setembro a novembro de 2017), acompanhamos cinco encontros de mutirão na Horta Comunitária QB, que foi fundada em 2015 por um grupo de moradores e frequentadores do JS. O perfil deste grupo é de pessoas interessadas na conservação da Natureza. Nestes mutirões foi possível conversar com os moradores e frequentadores de JS sobre os morros que contornam o bairro (Morro do Valqueire, Cachambi e Caixa de água). Nas falas destes moradores e frequentadores do bairro foram recorrentes as memórias de trilhas que percorriam os morros do JS. No entanto, foi unânime a fala sobre o afastamento das trilhas nos morros da região devido à insegurança na zona oeste. De todos os locais, o Morro do Cachambi foi o mais citado, especificamente devido às caminhadas ecológicas promovidas pelo Sr. Eduardo Carvalho. Entretanto, poucos moradores sabem subir sem um guia, fora a dificuldade de acesso, pois não há uma entrada livre direto para a APAMC a partir de espaços públicos, sendo necessário passar por dentro de terrenos privados. Também foi identificada uma voz saudosa nas falas dos moradores sobre a vontade de retornar à APAMC para os mutirões de plantio.

Ao longo da observação participante com os grupos de moradores envolvidos com a conservação das áreas verdes do bairro ficou evidente a carência de projetos atuantes na APAMC. Uma primeira iniciativa foi desenvolvida durante a primeira festa da primavera, promovida no dia 23 de setembro de 2017 (Figura 2a e 2b), em parceria com o grupo de performances artísticas "Geotales UNIRIO" (associado à três projetos de extensão desta universidade pública) que visa promover a conservação do Patrimônio Natural brasileiro (PONCIANO, 2018).

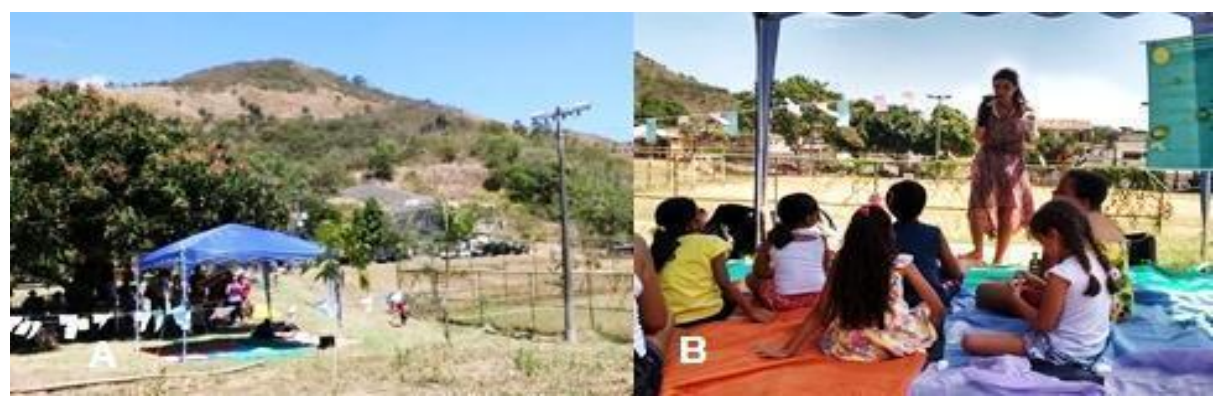

Figura 2: (a) Vista da APA MC a partir da Praça Quincas Borba; (b) narração de histórias para crianças na primeira Festa da Primavera. Fonte: fotos de Valéria Neves (2017).

Figure 2: (a) view of the APA MC from the Quincas Borba square; (b) storytelling for children on the first Spring Festival. Source: photos by Valéria Neves (2017).

Esta participação contou com a exposição "Inutilidades geopoéticas" do Geotales, e a performance de histórias narradas por uma das autoras. Além da 
sensibilização artística abordando a relevância do Patrimônio Natural de JS, foi realçada também a sensação de segurança em espaços verdes, pela ocupação em conjunto da praça. O repertório do Geotales, composto por histórias em prosa e verso, foi adaptado para abordar os temas transversais ao evento (Patrimônio Natural e a integração do ser humano com a Natureza). Os serviços culturais, assim como os demais serviços ecossistêmicos (suporte, regulação e provisão), foram correlacionados, por exemplo, com trechos do poema "Aninha e suas pedras", de Cora Coralina: "...Remove pedras, planta roseiras, faz doces. Recomeça. / E viverás no coração dos jovens / e na memória das gerações que hão de vir.".

Já nos trechos dos poemas "Retrato do artista quando coisa", de Manoel de Barros - "penso em renovar o homem utilizando as borboletas" - e "Canção mínima", de Cecília Meireles - "No mistério do sem-fim / Equilibra-se um planeta" - foram abordados conteúdos que visam uma integração com a Natureza por meio de intervenções antrópicas positivas. Na história "O menino e o couro" (SANTOS, 2017) os serviços ecossistêmicos foram mais enfocados e na história "Árvore de Pedra" (PONCIANO, 2015) os valores de cidadania e solidariedade inerentes ao compartilhamento de uma colheita, determinantes para a sobrevivência de um agrupamento humano, foram correlacionados com os usos das áreas verdes do JS.

$\mathrm{Na}$ primeira festa da primavera foi promovida uma comemoração com entrelaçamento de saberes a partir das demandas dos próprios moradores. Apesar de o evento ter sido direcionado para as crianças, este público não foi constante ao longo das atividades, o que pode ser associado ao hábito de visitas rápidas às praças. O público que participou mais efetivamente da programação, assim como das atividades na Horta Comunitária QB, foram adultos e idosos.

Devido ao esvaziamento das praças do JS, a pesquisa delimitou a área de estudo e de atuação na APAMC, mais especificamente no sistema de trilhas traçado ao longo das ações de reflorestamento numa porção de 10 hectares na face Norte do morro. Desde então, foram analisadas novas formas de sensibilização que fossem adequadas ao sistema de trilhas existentes na APAMC. Para isto, foi necessário compreender melhor a dinâmica das trilhas guiadas no local.

Um resgate da atividade de visitação que era feita pelos antigos voluntários foi feito por meio de ensaios, utilizando inclusive o mesmo nome, "Caminhadas Ecológicas". Foram realizados seis ensaios neste formato com público fechado, tendo como participantes os moradores atuantes em iniciativas de conservação das áreas verdes do bairro e seus respectivos convidados. Os eventos foram criados no Facebook de forma fechada (ou seja, apenas convidados teriam acesso) e divulgados nos grupos de WhatsApp do bairro, tendo os moradores como apoiadores e divulgadores. As atividades foram filmadas e debatidas posteriormente, num ciclo de observação-análise-proposta. Decorrente das análises obtidas pelos trabalhos de campo foram testados os melhores caminhos para maximizar os atrativos naturais e históricos da APAMC e as áreas mais adequadas para continuar o reflorestamento, por meio do plantio de mudas nativas de Mata Atlântica (produzidas pelos próprios moradores de JS, voluntariamente) (Figura 3).

Estas mudas são de sementes oriundas de árvores adultas da área reflorestada, como também de árvores dispostas em praças, calçadas e quintais das casas do JS. Como parte dos voluntários que participaram ao longo dos 22 anos de reflorestamento atualmente é idosa e não consegue mais subir a trilha ou atuar no limite da área recuperada, suas ações são concentradas na produção de mudas e 
manutenção da área mais próxima da sede. Usualmente a produção das mudas é feita em casa, e as plântulas são transplantadas para vasos maiores que os moradores doam, colocando-os no viveiro, à espera de um voluntário mais novo que queria plantá-las.

O viveiro é um espaço ao lado da trilha, logo no primeiro trecho após o portão de acesso à APAMC, que ainda contêm um sistema de irrigação. Neste local encontramos uma grande variedade de mudas, desde espécies exóticas, como as PANC's (Ora-Pro-Nóbis e Moringa), a espécies nativas da Mata Atlântica. A produção de mudas pelos antigos voluntários representa uma relação afetiva que ocorre de forma livre, sendo recorrentes os casos de mudas que morreram antes de serem plantadas, ou de raízes que alcançaram o solo e se estabeleceram no próprio viveiro. A ideia atual é tentar integrar a produção de mudas com o plantio, iniciando por um levantamento das espécies que são mais produzidas e os motivos desta seleção.

No dia 18 de novembro de 2017 ocorreu a primeira caminhada ecológica, tendo como público oito pessoas: dois antigos voluntários e seis jovens adultos (de 18 a 25 anos) (Figura 3b). A trilha utilizada percorreu o limite lateral oeste da área reflorestada, até seu limite superior, demarcado por uma Macaúba (percurso 1 Figura 3 - marcado em azul). Desta árvore seguimos um caminho reto pela área degradada até o ponto mirante, onde é possível apreciar a vista acima do dossel da área reflorestada. A escolha por este caminho foi devido ao perfil do grupo mais jovem, pois esta trilha tem características mais primitivas, como trechos não delimitados e alta declividade, o que poderia ser um atrativo para este perfil. Outro fator foi a manutenção do aceiro e o mês ser mais favorável para o plantio, sendo uma oportunidade para priorizar trechos de difícil acesso. Foram plantadas 18 árvores nativas da Mata Atlântica, transportadas em baldes junto a galões de água de cinco litros (área de plantio 1 - Figura 3). A atividade foi bem desenvolvida pelo grupo, de acordo com as expectativas para esta faixa etária. Entretanto, esta trilha não percorreu alguns pontos interessantes por dentro da área reflorestada, e este trajeto não alcançaria uma ampla faixa etária, pois o esforço físico é maior.

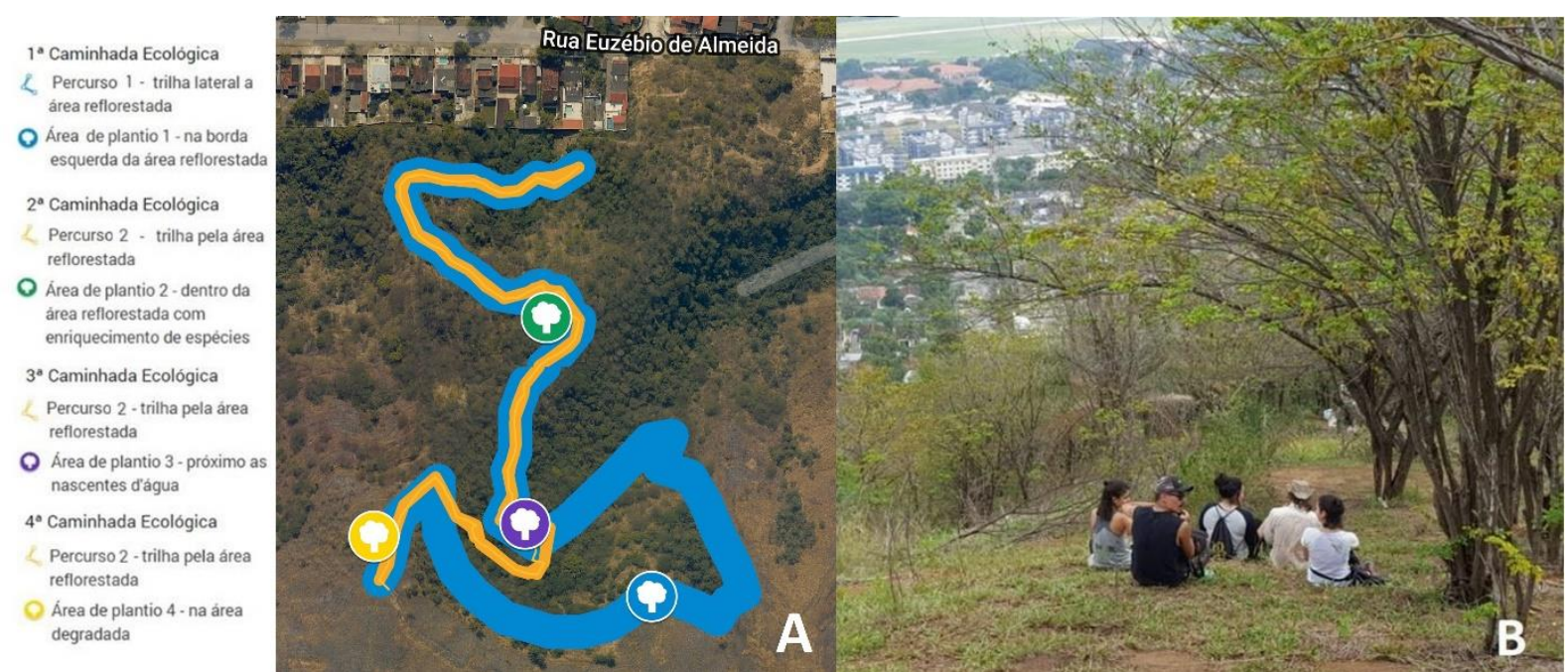

Figura 3: (a) Mapa dos percursos das trilhas e das áreas onde foram feitos os plantios; (b) Grupo da primeira caminhada ecológica no mirante. Fonte: fotos de Valéria Neves (2017).

Figure 3: (a) Map of the paths of the trails and the areas where the plantations were made; (b) Group of the first ecological walk in the lookout. Source: photos by Valéria Neves (2017). 
No dia 24 de novembro de 2017 foi promovida a segunda caminhada ecológica, com a mocidade do Centro Espírita Luís Sérgio, contando com a presença de um voluntário, nove jovens (12 a 18 anos), três jovens adultos (de 19 a 25 anos), dois adultos (26 a 59 anos) e um idoso (a partir de 60). A trilha escolhida percorreu a área reflorestada até o limite superior, seguindo até o mirante na área degradada (percurso 2 - Figura 3 - linha laranja). Foi feito um plantio de enriquecimento, introduzindo novas espécies nativas da Mata Atlântica dentro da área reflorestada (área de plantio 2 - Figura 3). Esta técnica consiste na substituição ou inclusão de uma maior variedade de espécies nativas da Mata Atlântica numa porção previamente reflorestada onde foram utilizadas plantas pioneiras, com pouca variedade de espécies. Neste evento foi implementada a etapa de abertura, narrando a história do reflorestamento da área e as recomendações de segurança, assim como a finalização com um lanche solidário e uma roda de conversa, quando os visitantes avaliavam a atividade. O plantio na área sombreada foi um destaque desse trajeto, sendo mais confortável que nas áreas mais elevadas, expostas ao sol. Este local possibilitou o contato dos visitantes com uma maior variedade de espécies, incluindo as 15 mudas plantadas (Ipê-Roxo, Ipê-Amarelo, Cotieira, PauFerro, Saboneteiras, Jatobás, Pau-Brasil, Aroeira, entre outras). No entanto, para este tipo de plantio foi necessário o manejo prévio da espécie pioneira Sabiá (Mimosa caesalpiniaefolia Benth.), que é muito trabalhoso. Como não havia ferramentas, tempo nem voluntários suficientes para fazer esta técnica de plantio numa área maior, o local selecionado teve de ser trocado.

No dia 2 de dezembro de 2017 ocorreu a terceira caminhada ecológica, com seis pessoas, sendo um voluntário, quatro jovens adultos e um adulto (Figura 4a). O percurso utilizado foi semelhante ao da segunda caminhada, diferindo apenas no local do plantio, que foi próximo à nascente de água (área de plantio 3 - Figura 3), desviando o caminho para realizar esta atividade e posteriormente retomando-o até o mirante, na área degradada. Foram plantadas dez árvores variadas de espécies nativas da Mata Atlântica. Assim como nas caminhadas anteriores, o trabalho de campo naquela semana envolveu o manejo da trilha, para que a atividade ocorresse com mais segurança e conforto. No entanto, esta porção da trilha é naturalmente mais úmida e próxima a uma depressão no relevo, onde o solo é mais escorregadio. Este cenário não foi muito atrativo para os visitantes, pois a sensação de risco foi desconfortável e alguns optaram por não adentrar na área íngreme para plantar, permanecendo no trajeto demarcado da trilha.

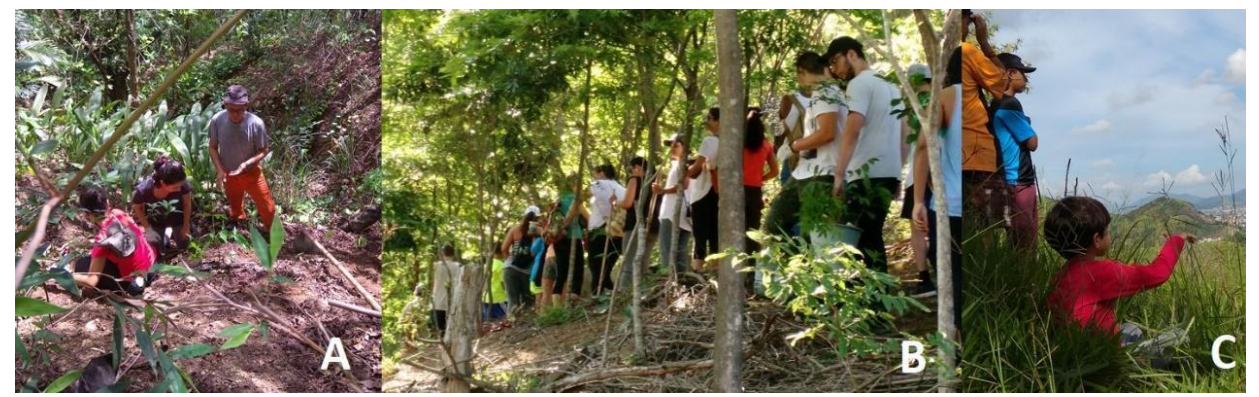

Figura 4: (a) 3a․ caminhada ecológica, no momento do plantio na área das nascentes de água; (b) 4은 caminhada ecológica, grupo percorrendo a área reflorestada; (c) menino acariciando as mudas e a grama na área degradada, demonstrando sua afeição. Fonte: fotos de Valéria Neves (2017 e 2018).

Figure 4: (a) 3rd ecological walk, the moment of planting seedlings in the area of the water springs;

(b) 4th ecological walk, the group passing through the reforested area; (c) boy giving love to the seedlings and the grass, in the degraded area, showing his affection.

Source: fotos by Valéria Neves (2017 and 2018). 
No dia 17 de dezembro de 2017 ocorreu a quarta caminhada ecológica, com 32 pessoas, incluindo um voluntário, quatro crianças, dezoito jovens adultos, sete adultos e dois idosos (Figura 4b). O aumento significativo do público nesta trilha pode ser associado com a participação dos voluntários da Horta Comunitária QB e a divulgação pelo nome "Caminhada Ecológica: Mutirão Natalino". A proximidade do Natal, um período de férias, pode ser associada a esta maior procura do público por atividades ao ar livre. $O$ percurso foi semelhante ao das caminhadas ecológicas anteriores (percurso 2 - Figura 3 - linha laranja), diferindo no local de plantio, ao longo do trecho entre a Macaúba (limite da área reflorestada) e o mirante (área de plantio 4 - Figura 3). Esta foi a primeira vez em que os berços para mudas foram preparados previamente, o que foi feito num trabalho de campo com o apoio de cinco novos voluntários (jovens adultos que participaram das caminhadas ecológicas anteriores). O solo era escasso, composto basicamente por rochas. Foi necessária uma manhã inteira para a preparação dos berços de forma manual, com enxadas, o que seria inviável para realizar junto com o momento de plantio com os visitantes. Nesta caminhada a abertura contou com uma nova narrativa, sobre a história geológica da região, além das partes que já eram realizadas anteriormente. Esta trilha foi confortável para todas as idades.

Comparando as quatro atividades, o trajeto da quarta trilha perpassou por um maior número de pontos atrativos, e teve uma área mais ampla para fazer o reflorestamento, mais adequada para grupos grandes. O plantio foi mantido como uma das atividades da nova proposta de trilha, pois além de ser uma forma efetiva de conservação, também promove uma sensação de pertencimento. Sobre a perspectiva de sensibilização, este trajeto também foi mais interessante. Observouse que quando o plantio era feito em outras porções, e não no mirante, havia um interesse menor de explorar o local, o que pode ser associado a uma retenção dos visitantes dentro dos trajetos das trilhas, pois era ao longo deles que era feito o plantio. Já o grupo que plantou na área degradada, próximo ao mirante, pode apreciar a vista e alguns visitantes foram mais curiosos, subiram para explorar outros pontos ou lateralizaram sua exploração pela área degradada, circulando livremente. Estes momentos espontâneos foram muito férteis para as correlações afetivas e reflexões introspectivas do eu com a Natureza que me habita, sendo incorporados na criação da nova proposta de trilha geopoética. Nos eventos seguintes começaram a ser testados outras formas de sensibilização que poderiam ser incorporadas à nova trilha.

A quinta caminhada ecológica ocorreu no dia 2 de fevereiro de 2018, como comemoração do aniversário de 11 anos de um morador. Ela pode ser considerada um dos primeiros frutos da sensibilização promovida ao longo da pesquisa, uma vez que 0 aniversariante e sua família conheceram o projeto de reflorestamento na época do Sr. Eduardo, retornando na quarta caminhada ecológica, e pedindo que essa comemoração fosse na APAMC. O grupo de visitantes foi de 23 pessoas, dentre estes um voluntário, dois novos voluntários, cinco adultos e 15 crianças (de 5 a 12 anos). 0 envolvimento e a sensibilização das crianças foram diferentes das demais faixas etárias. Um antigo voluntário falou sobre a importância das plantas, que elas são seres vivos que sentem como nós, conscientizando as crianças para não puxarem os galhos das árvores ao longo do caminho. Durante o plantio muitas crianças conversaram com suas mudas e em seguida foram explorar a APAMC, andando pela área degradada e fazendo inúmeras perguntas sobre o reflorestamento, a biodiversidade do passado, entre outros temas. Um menino em 
especial, de cinco anos, sentou-se entre a grama na área degradada e dedicou aquele momento para cantar para as plantas, fazendo carinho em suas folhas (Figura 4c). Na descida este menino abraçou todas as árvores que conseguiu, enquanto dizia que as amava. De volta na sede, na roda de conversa sobre a atividade foi perguntado o que os visitantes mais gostaram. Na fala dos adultos foi enfatizada a possibilidade das crianças terem mais contato com a Natureza, enquanto na fala das crianças a vista foi mais citada, e duas crianças citaram árvores (a orelha de macaco, que encontramos sementes ao longo da trilha, e "aquela árvore branca", que se trata de um pau-ferro), demonstrando o potencial das narrativas e contos sobre a vista dos arredores e as espécies da flora local, que poderiam ser integrados na atividade.

Ainda no mês de fevereiro de 2018 a cidade do Rio de Janeiro foi atingida por uma forte tempestade na madrugada do dia 15. No bairro JS, mais de 100 árvores caíram ao longo das calçadas, obstruíram ruas, derrubaram postes, muros e destruíram canos. Após esta tempestade apareceu uma súbita rejeição por árvores nas calçadas e nos quintais, uma das características do bairro. O cenário na área reflorestada não foi diferente do restante do bairro. A degradação causada pela tempestade foi tamanha que todas as trilhas foram inviabilizadas. Nos meses de fevereiro até abril os trabalhos de campo se concentraram no manejo e recuperação da trilha que estava sendo utilizada pelos visitantes.

A visitação retornou no dia 21 de abril de 2018, com a sexta caminhada ecológica. Este evento teve 19 participantes (quatro voluntários, três novos voluntários, duas crianças (de 5 e 9 anos), quatro jovens adultos, quatro adultos e duas idosas). Foram plantadas 15 árvores nativas da Mata Atlântica. Para que a atividade fosse confortável para todos, o grupo se dividiu em dois. Um com idosos e as crianças e seus respectivos responsáveis, que ficaram junto com uma das autoras, e os outros com os demais participantes. Segundo as falas na roda de conversa a atividade atendeu a expectativa de todas as faixas etárias. Entretanto, a falta de integração entre o grupo foi interpretada como um empobrecimento da atividade, pois os idosos já haviam subido a trilha no passado (inclusive entre eles estava a esposa do fundador do reflorestamento, que narrou inúmeras memórias ao longo da trilha), e a parte do grupo que ficou separada não teve a mesma experiência. A troca de olhares entre as faixas etárias é benéfica para ambos os lados. Por exemplo, para os adultos de forma geral ela possibilita tangenciar a forma peculiar com que as crianças enxergam o mundo por suas próprias lentes, reparando em detalhes diferentes do local. Para as crianças, fazer a trilha junto com os adultos e idosos potencializa a passagem de memórias afetivas que as outras gerações criaram com o local e diversos elementos da Natureza que as crianças estão conhecendo pela primeira vez. A partir de então foram inseridos na trilha pontos onde sempre é realizado o agrupamento de todos os visitantes, possibilitando a integração entre os diferentes ritmos de condicionamento físico e faixas etárias, que também ajudam a criar momentos mais livres para as conversas entre os visitantes e a exploração dos locais. Estes pontos estratégicos para o agrupamento foram utilizados para a criação de instalações artísticas, numa abordagem que visa atrair a atenção dos visitantes para vários elementos bióticos e abióticos ao longo da trilha, diminuindo o ritmo da caminhada para interagir e explorar o ambiente, especialmente nesses locais que se abrem (de forma tanto espacial quanto temporal) para a percepção da nossa relação com a Natureza. 
Ao longo desse período (novembro de 2017 a abril de 2018) também foi efetuado o manejo das trilhas e o mapeamento por geolocalização dos pontos de valor estético, didático, turístico, de lazer, de biodiversidade e/ou geodiversidade mais relevantes para elaboração da trilha geopoética. A partir da observação participante, notamos que os principais motivos para participar das caminhadas ecológicas foram a vista do mirante, o plantio de mudas e o histórico das iniciativas de conservação da APA. Também foi analisado os tipos de intervenções desejados para a trilha que variaram desde identificação de fauna, uso de recursos tecnológicos (como drones), performances poéticas ao mínimo de estrutura e manutenção da trilha.

Foi identificada uma falta de integração entre as ações voluntárias na área reflorestada da APAMC, que dificultavam ou mesmo inviabilizavam o envolvimento de novos voluntários. Os visitantes e moradores envolvidos em outras iniciativas associadas às áreas verdes do bairro queriam participar, mas precisavam de uma estrutura e variedade de horários para abraçá-los e nortear as suas ações. Uma vez que a pesquisa é participativa, no final das caminhadas ecológicas todos os visitantes foram convidados para serem voluntários, sendo uma forma de iniciá-los em ações de conservação na APAMC. No entanto, apenas três jovens adultos engajaram efetivamente no trabalho voluntário.

\section{O tronco da Geopoética}

No período entre os meses de abril a junho de 2018 ocorreu a segunda etapa da pesquisa, enfocando a busca de metodologias de sensibilização para compor uma nova proposta de atividade a partir da estrutura desenvolvida ao longo das caminhadas ecológicas. Estas metodologias foram testadas em três ensaios, que constituem o "tronco" da Geopoética da APAMC. O formato foi debatido com os voluntários (novos e antigos) que acompanharam os encontros semanais de trabalhos de campo, reelaborando a atividade a cada evento. Nos ensaios foram testados principalmente os métodos avaliativos, por meio de um estudo observacional descritivo, utilizando-se questionários anônimos aplicados a uma amostra pareada, com um questionário antes da atividade da visitação da trilha e outro posterior à visitação, com o intuito de verificar o efeito da atividade na trilha no indivíduo, assim como avaliar o atendimento das expectativas que eles tinham antes da visitação. Além do registro contínuo por fotos e filmagem, foram padronizados pontos chaves da trilha pra realizar este registro, assim como modos de fazê-lo de forma discreta, a fim de obter uma reação mais espontânea do grupo de visitantes (por exemplo, após estes testes as câmeras foram acopladas às roupas - Figura 11b). Quanto à abordagem, foi utilizada a narrativa como viés de comunicação ao longo de toda a atividade, diversificando as vozes com o treinamento de novos voluntários para guiarem junto a uma das autoras, promovendo um espaço mais convidativo de trocas. Neste período, os trabalhos de campo incluíram a interseção dos sistemas híbridos com a Arte da Terra, por meio da investigação empírica da trilha e da experimentação artística dos elementos naturais dispostos ao longo dela.

As três trilhas guiadas tiveram público aberto, com pré-inscrição por meio de um evento no Facebook, tendo em vista que a metodologia de sensibilização pretendia alcançar não só os moradores do bairro JS, mas também visitantes de outros locais. A visitação turística tem o potencial de criar memórias afetivas, promovendo uma conscientização ambiental que visa à conservação do Patrimônio 
Natural não só da APAMC como dos outros lugares que as pessoas alcançadas tenham mais contato. Desta forma as vivências de ecoturismo, associando o lazer com atividades de menor impacto ao meio ambiente, impulsionam diversas mudanças no cotidiano.

A primeira trilha guiada ocorreu no dia 19 de maio de 2018, com público aberto e 32 participantes (Figura 5a). Destes, um era voluntário, três guias, seis jovens, cinco jovens adultos, nove adultos e oito idosos. Uma participação interessante foi a de quatro casais (adultos e idosos) de ex-voluntários do reflorestamento. Eles acreditavam que não só as visitações como todas as atividades na APAMC haviam sido encerradas em 2014, sendo um encontro rico de histórias e entusiasmo. Foram preparados, previamente, nove berços para o plantio, devido às condições do solo. No momento do plantio novos berços foram abertos pelos guias, um antigo voluntário e nove visitantes que se propuseram a ajudar. Apesar de a participação ter sido interessante, abrir os berços no momento do plantio demandou muito tempo e esforço físico dos visitantes, por isso foi avaliado que seria mais adequado abrir todos os berços antes da realização da trilha. Foram plantadas 26 árvores de espécies variadas, nativas da Mata Atlântica. Após o plantio, o grupo permaneceu apreciando a vista, que devido à boa visibilidade neste dia alcançou a Serra dos Órgãos, identificada pelo Dedo de Deus e a Baía de Guanabara.

Este foi o primeiro evento com aplicação do questionário. Os visitantes sinalizaram que o questionário estava muito extenso, com 47 perguntas, e repetitivo, demonstrando que o método de amostra pareada não estava claro. O questionário foi reformulado, assim como o texto introdutório, para esclarecer o método de utilizar amostra pareada por indivíduo (isto é, um mesmo indivíduo respondendo em dois instantes, antes e após a trilha). Dos 32 participantes, 25 responderam ao questionário, pois três eram guias, além da presença de um antigo voluntário, sua esposa e dois jovens que se recusaram a responder. Destes 25 , a maioria eram mulheres $(64 \%)$, em sua primeira visita $(88 \%)$. A escolaridade foi a partir de ensino fundamental completo (12\%), sendo a maioria $(64 \%)$ de curso superior (completo ou incompleto) ou pós-graduação. Seis destes visitantes eram moradores do JS, 13 de bairros próximos (Vila Valqueire, Mallet, Taquara, Realengo, Magalhães Bastos, Bento Ribeiro) e seis de bairros mais distantes (Méier, Pechincha, Campo Grande, Coelho Neto, Senador Camará). Isto demonstra que o veículo de divulgação foi eficaz para além dos limites do bairro. Quanto à atividade na trilha, foram recorrentes os pedidos por megafones e para plantar um número maior de mudas. Foi observado que nem todos visitantes plantaram, enquanto outros plantaram mais de uma muda. Isto pode ser associado a um conhecimento prévio de alguns visitantes sobre plantio, não precisando de apoio. Ao mesmo tempo, foi uma sinalização de que alguns visitantes requerem uma maior orientação para plantar as mudas. O plantio é o momento mais evidente de interferência dos visitantes no espaço, tendo um grande potencial de sensibilização. Analisando as relações dos visitantes com as mudas, optou-se por plantar em grupos, em vez de incentivar uma relação individualista com as mudas, assim como a rega das mudas previamente plantadas. Foram pesquisadas outras formas de sensibilização associadas ao plantio para compor a trilha geopoética, que será abordada mais abaixo. 


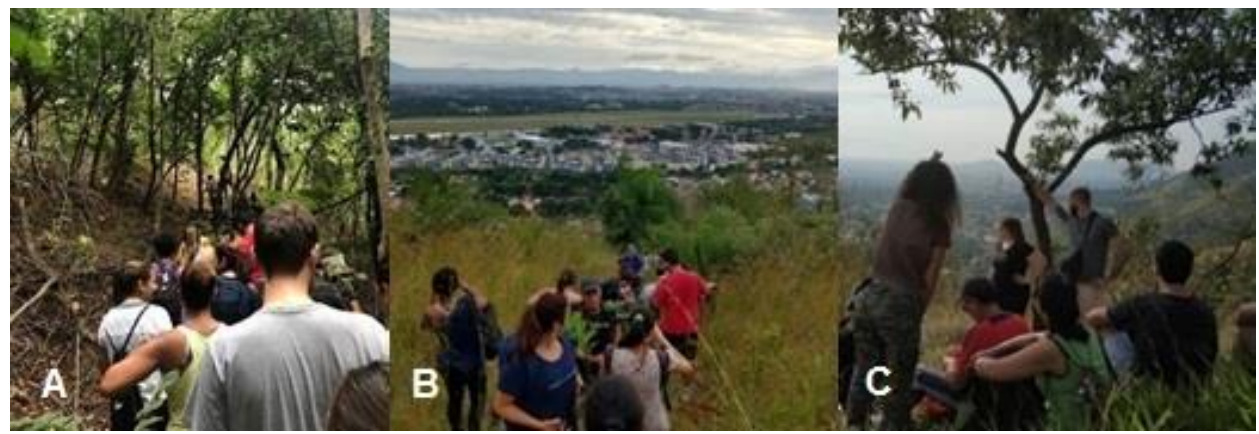

Figura 5: (a) $1^{\circ}$ trilha guiada, o grupo percorrendo a área reflorestada; (b) 2 trilha guiada, o grupo percorrendo a área degrada; (c) $2^{\circ}$ trilha guiada, vista no mirante.

Figure 5: (a) 1st guided trail, the group passing through the reforested area; (b) 2nd guided trail, the group passing through the degraded area; (c) 2nd guided trail, the group enjoying the view on the lookout.

Fonte: fotos de Valéria Neves (2018).

Source: photos by Valéria Neves (2018).

No mês de junho de 2018, ocorreu a segunda trilha guiada no dia 14, com a presença de 25 visitantes (Figuras $5 b$ e $5 c$ ). O público foi composto por três guias, duas crianças (de 5 e 7 anos), três jovens adultos, onze adultos, cinco idosos. Alguns visitantes haviam participado da trilha guiada no mês de maio (6 dos 22). $O$ baixo quantitativo pode ser associado às condições climáticas, chuvosas. Neste evento já foram testadas algumas modificações. Após a recepção foi feito um aquecimento em duplas, sendo uma das formas de sensibilização e integração do grupo. Em seguida foi feita uma vivência sensorial com os visitantes, que vendados exploravam seis caixas, cada uma com um elemento da APAMC: pimenta rosa, folhas de Cravo-da-Índia, pedaços de troncos de Jerivá em decomposição, fragmentos de rocha, terra e sementes de Orelha de Macaco. Todos os materiais foram colhidos na própria área reflorestada.

Outra modificação foi o início da descentralização da voz, numa contraproposta aos megafones, pois os guias foram criando diálogos ao longo da trilha, enfocando o interesse de cada visitante, instigando ainda mais suas próprias percepções do espaço. A mudança de comportamento dos visitantes foi notória. Nos eventos anteriores foi recorrente alguns visitantes tentarem ultrapassar os outros para se aproximarem dos guias. Com todos os guias pré-dispostos e capacitados para conversar sobre o histórico, biodiversidade, geodiversidade e curiosidades do local, os visitantes aparentaram estar menos ansiosos, caminhando calmamente pela trilha. Esta abordagem se mostrou mais promissora para sensibilizar e diversificar as formas com que os visitantes podem interagir com a teia de elementos bióticos e abióticos, conteúdos e sentimentos atrelados à APAMC.

$\mathrm{Na}$ etapa de plantio, foi feito uma demonstração de como transplantar as mudas, convidando um visitante para participar junto à guia, e os demais observaram. Em seguida os quatro guias se distribuíram para orientar o plantio e garantir que todos os visitantes fossem convidados a plantar em duplas ou trios, tendo auxílio, se necessário. Foram plantadas 22 mudas de espécies nativas variadas da Mata Atlântica. No momento após a descida da trilha guiada, de volta a sede, a aplicação do questionário foi concomitante ao lanche solidário em conjunto com uma intervenção poética, com poemas de diversos autores escritos em filtros de café. Estes textos foram retirados do repertório do Geotales. No final, os visitantes foram convidados a visitar a Horta Comunitária QB, sendo guiados pelos moradores envolvidos. Este foi um teste de como integrar as iniciativas de conservação das áreas verdes do bairro JS. Este evento também foi acompanhado pelo SulacapNews 
(o jornal do bairro), o qual entrevistou a equipe para o documentário sobre a história do bairro que foi lançado no dia 27 de outubro de 2018, no Cinesystem do Parque Shopping Sulacap.

O questionário, com 40 perguntas, ainda foi considerado extenso pelos visitantes. O número de respostas foi 17 questionários, mas ainda que houvesse perguntas não preenchidas, a amostra pareada foi bem compreendida. A maioria dos visitantes estava em sua primeira visita $(76,5 \%)$, e nove dos visitantes são moradores do JS, e os demais de bairros vizinhos (Vila Valqueire, Magalhães bastos, Bangu, Padre Miguel). Não houve visitantes de bairros distantes, o que pode ser associado ao tempo chuvoso. Esta versão do questionário foi reduzida para ser testada novamente na terceira trilha guiada.

Na madrugada do dia 23 para o dia 24 de julho de 2018 ocorreu um incêndio que só foi parado a noite, devido à ação de bombeiros e guardas parques do INEA (Figura 6a). Esta queimada iniciou próximo ao topo do morro e se alastrou pelos morros da região, adentrando a área reflorestada, inclusive na porção em que os visitantes plantaram desde novembro de 2017, destruindo cerca de 400 mudas que tinham sido plantadas anteriormente. As queimadas são recorrentes no período de junho nas áreas verdes na cidade do Rio de Janeiro, principalmente devido a balões, estando associadas também ao mato seco típico do inverno (INEA, 2013). Este cenário não é diferente no bairro do JS, que já sofreu queimadas para obtenção de pasto para o gado ou por outros motivos, como para reduzir a incidência de mosquitos, gerar segurança e visibilidade, assim como afastar a fauna (cobras), segundo os moradores. Por isto, desde o início das ações de reflorestamento os voluntários faziam aceiro para proteger a área de possíveis incêndios. Os incêndios em JS costumam durar dias, mas desta vez a mobilização social foi tamanha que o fogo foi combatido a tempo. Foi feita uma corrente de denúncias até os guardas parques serem acionados, seguidos por uma corrente física de transporte de água em baldes para apoiar os guardas parques que combatiam os focos de incêndios. A maioria dos participantes desta mobilização foram os idosos, que participaram voluntariamente do reflorestamento.

Neste dia, foram compartilhadas diversas histórias sobre queimadas na APAMC, após os moradores verem o fogo por sua janela, demonstrando um elo afetivo com este fragmento florestal. Após a vivência deste momento, o tema das queimadas ilegais na zona oeste do Rio de Janeiro foi incluído na trilha por meio de instalações artísticas na proposta final da trilha geopoética, que será abordada mais abaixo.

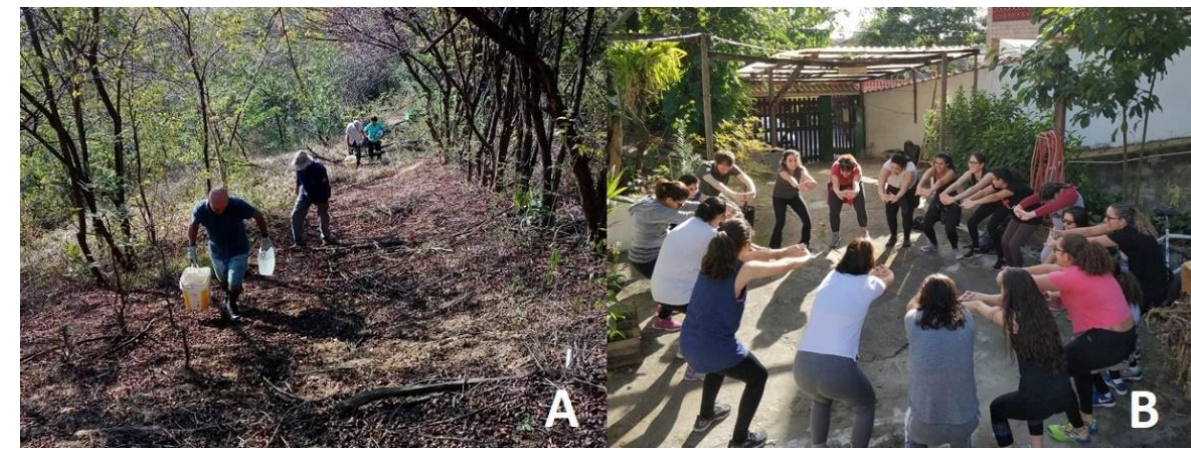

Figura 6: (a) Moradores subindo a APAMC com baldes de água para ajudar os guardas parque; (b) $3^{\text {a }}$ trilha guiada, com o alongamento na sede. Fonte: fotos de Valéria Neves (2018).

Figure 6: (a) Residents walking on the trails of APAMC carring buckets with water to help the park guards; (b) 3rd guided trail. Source: photos by Valéria Neves (2018). 
No dia 30 de junho de 2018 ocorreu a terceira trilha guiada com um grupo fechado, para a mocidade feminina da maçonaria de Praça Seca (Figuras 6b). 0 grupo foi de 25 meninas e mulheres (duas crianças, sete jovens, doze jovens adultas e quatro adultas), além da presença de um voluntário e dos três guias. As modificações feitas na última trilha foram mantidas. No entanto, na preparação dos berços foi utilizada uma perfuradora de solo a gasolina, viabilizando o plantio numa escala maior. Também foi testado o plantio de três sementes de feijão-de-porco por muda, para auxiliar em seu desenvolvimento. Esta leguminosa promove uma cobertura do solo, diminuindo a evaporação da água e impede a ocorrência de gramíneas, auxiliando na nitrificação e descompactação do solo (MAPA, 2007). Entretanto, devido à falta destas sementes, este procedimento não foi realizado nas trilhas seguintes.

A atividade foi adequada à faixa etária do público, o conforto ao longo da trilha foi um dos pontos sinalizados nos comentários dos questionários. Um fato interessante é que dentre as visitantes duas eram moradoras do JS e não conheciam a APAMC, enquanto três visitantes, de Vila Valqueire e Realengo, disseram conhecer a APAMC por sua paisagem, à distância.

Esta versão do questionário também foi reformulada para a sua versão final. Entretanto, uma das perguntas que não sofreu alteração desde o primeiro protótipo foram: "Escreva 5 palavras que representam a sua expectativa com a trilha guiada" e "Escreva 5 palavras que representam sua experiência com a atividade que acabou de realizar". Somando as respostas das três trilhas guiadas, podemos observar as escolhas de antes (Figura 7a) e depois da trilha (Figura 7b) nas nuvens de palavras abaixo.
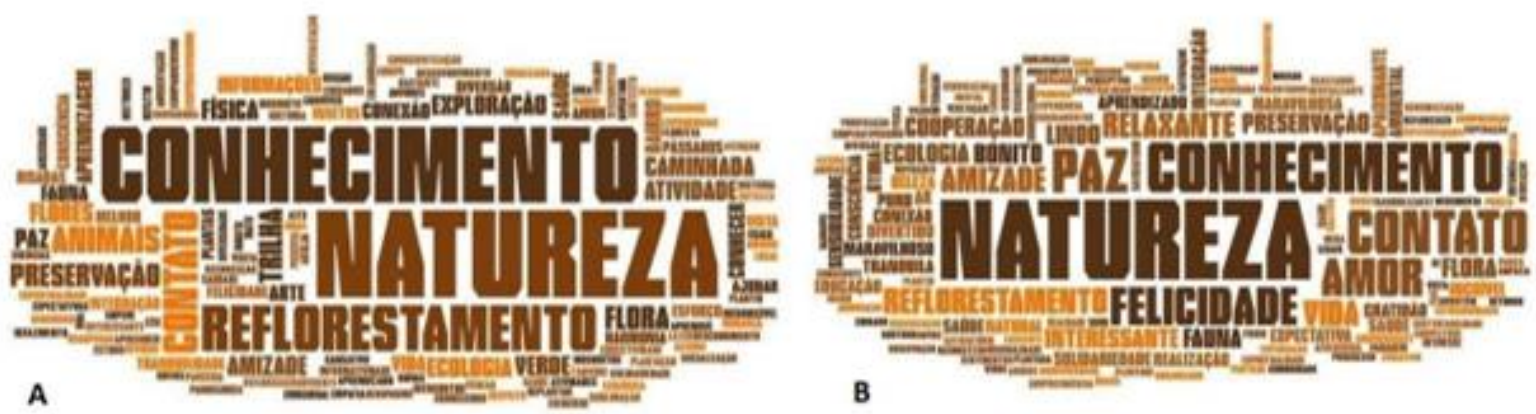

Figura 7: Nuvens de palavras a partir de dados dos questionários. (a) aplicados antes das trilhas guiadas; (b) depois das trilhas guiadas.

Figure 7: Word clouds from the questionnaires data. (a) applied before the guided trails; (b) applied after the guided trails.

Observando as nuvens de palavras acima é evidente que as palavras mais recorrentes em ambos os casos são Natureza e Conhecimento. Já quanto às palavras diferentes que aparecem nas nuvens, podemos observar o viés de sensibilização afetiva nos eventos de visitação realizados. Os termos encontrados na Figura $7 \mathrm{a}$, que podem ser interpretados como uma busca dos visitantes por informações (como preservação, animais, ecologia, caminhada, exploração) cedem espaço na Figura $7 \mathrm{~b}$ para termos mais associados com as suas sensações (como felicidade, paz, amor, vida, amizade, relaxante). Um fato interessante é que a palavra trilha e caminhada, que aparecem na Figura $7 a$ não surgiram na $7 \mathrm{~b}$, e a palavra reflorestamento foi menos recorrente. Uma vez que as percepções despertadas pela atividade estão além de uma atividade didática e física ao ar livre, 
as palavras após a trilha demonstram uma maior integração dos visitantes com a teia de elementos bióticos e abióticos, significados e memórias afetivas que estão atreladas à APAMC.

Outras questões que não sofreram alteração e reafirmam esta expectativa por uma atividade cultural e não necessariamente uma atividade ao ar livre ou educacional (como uma aula de campo, onde o conhecimento é o principal objetivo) foi "Você tem interesse nos temas abaixo?", nos questionários antes da trilha, e "Sua expectativa foi alcançada?", no questionário posterior à trilha, ambos com cinco variáveis (1. Biodiversidade, 2. História Geológica, 3. Histórico do Bairro, 4. Esforço físico necessário, 5. Contato com a Natureza.), tendo como alternativas de respostas notas de 1 a 5 (1. não, totalmente, 2. não, parcialmente, 3. indiferente, 4. sim, parcialmente, 5. sim, totalmente). No geral, o contato com a Natureza teve um grande interesse da maioria dos visitantes, e esta expectativa foi bem alcançada; o esforço físico raramente despertou grande interesse, mas a expectativa foi bem alcançada na maioria das vezes, demonstrando um conforto na trilha. O histórico do bairro teve um interesse nota 4 e foi alcançado para a maioria, enquanto a biodiversidade teve um alto interesse, alcançado parcialmente, o que pode ser associado com a expectativa de ver animais ao longo da trilha, o que é raro. Já a história geológica teve um baixo interesse, nota 3, para a maior parte dos participantes, e foi parcialmente alcançado. Este bloco de perguntas no questionário foi importante para direcionar o desenvolvimento da trilha geopoética, no entanto, não foi utilizada no questionário final, onde a atividade foi analisada de forma interdisciplinar.

Por meio da interpretação dos dados obtidos nos questionários, assim como das filmagens da interação dos grupos de visitantes ao longo da trilha, foi possível compreender que a troca por vivências, sensações e interações com os demais organismos demonstraram ser mais desejadas que as falas teóricas em torno do que estava sendo experimentado. Norteando 0 desenvolvimento da trilha geopoética, numa abordagem para dar voz ao próprio ambiente por meio das Artes, criamos um espaço livre de interação para os visitantes, onde os guias observaram e identificaram o que foi cativando cada visitante para criar diálogos no local e compartilhar os conhecimentos previamente levantados.

Neste processo de desenvolver uma abordagem mais sensível e individualizada, participamos de dois eventos que possibilitaram a conversa sobre a proposta com uma ampla faixa etária. Um deles foi a segunda festa de primavera da Horta Comunitária QB, no dia 30 de setembro de 2018, reunindo por volta de 80 moradores. De forma semelhante à primeira festa da primavera, o grupo Geotales da UNIRIO colaborou com a exposição "Inutilidades geopoéticas" (Figuras 8a e 8b, próxima página).

Neste evento sete crianças foram contempladas pela narrativa do conto do Mapinguari (SANTOS et al., 2016), adaptado para o cenário de Mata Atlântica, utilizando uma caixa sensorial simulando o pêlo das preguiças gigantes pleistocênicas (Figura 8d). A atividade seguiu com uma trilha guiada pelo espaço da horta, onde as crianças foram instigadas a identificar a presença das ações dos seres humanos naquele ambiente, perpassando exemplos bons e ruins. No final as crianças foram convidadas a plantar mudas de flores, nos pés das árvores adultas, formando consórcios e contribuindo para atrair a fauna. Já para o público adulto foi feita uma oficina de macramê para suporte de vasos de plantas, visando uma valorização dos conhecimentos da terceira idade, num momento de troca sobre os possíveis pontos e formatos de vasos (Figura 8c). 


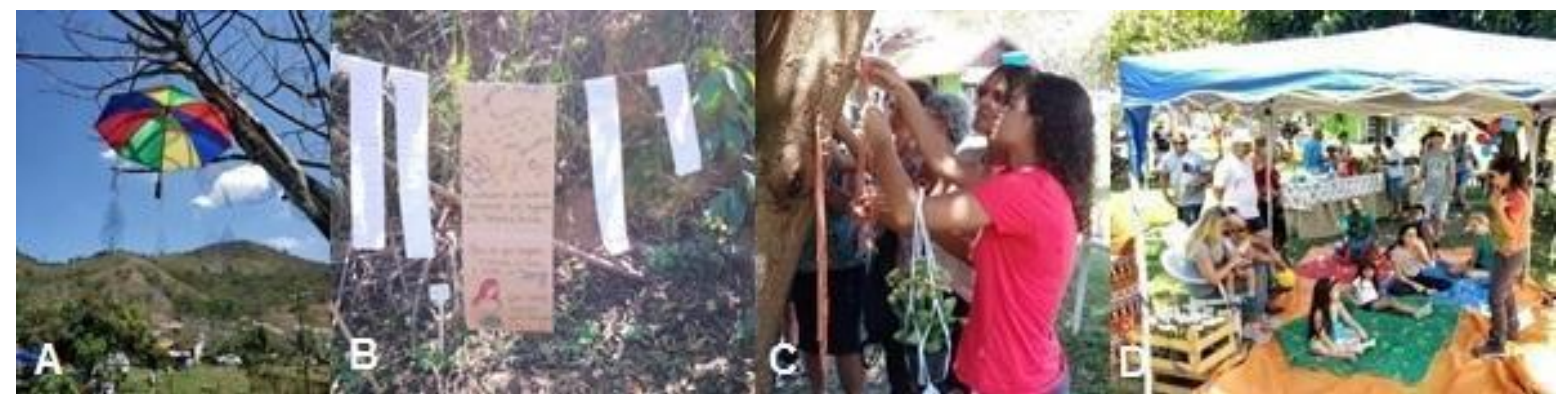

Figura 8: Segunda festa da primavera. (a) instalação Chuva de Poesia do grupo Geotales; (b) Instalação Varal de Higiene Mental do grupo Geotales; (c) Oficina de macramê; (d) Narração de história para crianças. Fonte: fotos de Valéria Neves (2017 e 2018).

Figure 8: Second spring festival. (a) installation Poetry Rain of the group Geotales; (b) installation Mental Hygiene of the Geotales group; (c) macrame workshop; (d) storytelling for children.

Source: photos by Valéria Neves (2017 and 2018).

No dia 27 de outubro ocorreu o lançamento do documentário "Jardim Sulacap: primeiro projeto de moradias populares do Brasil" no cinema do bairro, o Cinesystem do Parque Shopping Sulacap, em duas sessões, com um público de 516 moradores. A história começa a ser contada nos anos 1800, quando a inglesa Maria Grahan (preceptora de uma princesa) e Magalhães Corrêa (conservacionista e autor do livro O Sertão Carioca) passavam nas imediações quando o bairro ainda era apenas uma fazenda, chegando até os dias de hoje. O documentário enfoca a criação do bairro e a forma de vida de seus moradores, ressaltando o cenário, cercado por morros e Natureza exuberante. A participação de uma das autoras no documentário foi numa entrevista no topo da APAMC, durante a segunda trilha guiada, sobre as áreas de proteção ambiental, o projeto de reflorestamento e os valores (turístico, recreação, entre outros) atrelados ao perfil "verde" do bairro, interdependente das áreas abordadas neste projeto. Esta trilha foi filmada, compondo as imagens do documentário que representam o bairro atualmente, assim como alguns trechos mais reflorestados foram utilizados para ilustrar a época das fazendas, anterior ao desmatamento. O lançamento do documentário foi um momento de divulgação das ações de recuperação ambiental voluntárias que ocorrem na APAMC, assim como desta pesquisa-ação. Após a exibição do filme, no momento de conversa com moradores, foram recorrentes os comentários de interesse em participar das trilhas, sobretudo da terceira idade, e sobre o desconhecimento das leis que protegem estas áreas verdes ou da proximidade entre o bairro do JS e o PEPB.

\section{O DOSSEL da Geopoética}

A partir da análise dos dados levantados ao longo destes treze eventos, o novo produto foi direcionado para uma abordagem artística, culminando na elaboração da trilha geopoética D.O.S.S.E.L. - Despertando Olhares Sensíveis Sustentáveis Ecológicos e Lúdicos -, que integra os seres humanos, Natureza, Arte e Tecnologia no "dossel" da APAMC. O tipo de produto desejado pelos moradores do JS foi debatido ao longo de todos os eventos, ficando evidente a busca por uma atividade de lazer ao ar livre associada com a troca de conhecimentos de várias áreas, de forma leve e lúdica.

A trilha geopoética D.O.S.S.E.L. é composta por uma obra de arte - TEIA DOSSEL - fornada por 13 instalações artísticas, os GeoLiVes (Geopoetic Life Vessels ou Reservatórios de Vida Geopoética), compondo uma narrativa única que 
promove a imersão sensorial no ambiente da APA MC e a sua conservação por meio da afetividade, pertencimento e responsabilização social. As instalações são como adensamentos na teia, eclodindo ao longo da trilha pela sobreposição dos diversos fios que compõem a APAMC (usos e histórico do local, memória afetiva, serviços ecossistêmicos, biodiversidade, geodiversidade, valores científicos, didáticos, estéticos, recreativos e turísticos, entre outros).

O espaço contemplado pela trilha geopoética foi delimitado como um circuito, onde a subida e descida são diferentes (FEMERJ, 2015). Esta escolha teve o intuito de diluir os pontos visitados ao longo do trajeto, assim como manter o interesse dos visitantes em explorar a APA ao longo de toda a atividade, por não repetir os locais. Nos ensaios, utilizando claramente as mesmas trilhas para a subida e descida, notamos que durante a descida os visitantes estavam com a sensação de terem esgotado as possibilidades de visitação. A mudança de comportamento de alguns visitantes (adultos entre 30 e 50 anos) foi drástica, aumentando o tom de voz, conversando sobre seus compromissos seguintes e utilizando os celulares na descida. Esta transformação demonstrou uma quebra da sensibilização, como se a atividade já tivesse acabado e os visitantes retornassem para a sua rotina de preocupações do asfalto. Para formar este novo circuito foram reabertos caminhos antigos na descida, trilhas que não eram mais utilizadas que passaram a conectar algumas partes que já tinham sido testadas. Outra vantagem é que os visitantes geralmente não percebem que alguns trechos da descida são os mesmos da subida, pois como a forma de acesso a eles muda, o grau de localização de cada pessoa na área também varia, podendo enxergar com olhos diferentes os mesmos elementos durante o final da atividade, após as atividades de sensibilização terem sido realizadas na trilha.

Durante os trabalhos de campo foram identificadas cinco áreas com características diferentes ao longo do trajeto da trilha a partir de elementos da biodiversidade e da geodiversidade, dos dosséis de cada área e suas respectivas sensações térmicas, além da associação dos locais com as narrativas dos moradores do JS. Estas cinco áreas são 1. Jardim, 2. Enriquecimento, 3. Nascente D’água, 4. Degradada, 5. Regeneração (Figura 9a), sendo o circuito composto por partes diferentes de cada área no caminho de subida $(1>2>3>4)$ e descida $(4>2>5>1)$. Este circuito tem a duração de 1 hora e 30 minutos de caminhada. No entanto, como são realizadas diversas atividades de sensibilização ao longo do circuito, o evento como um todo tem duração de quatro horas, sendo 30 minutos de abertura, três horas percorrendo a trilha e 30 minutos de encerramento. $O$ percurso é de aproximadamente de 1.380 metros, sendo 620 metros de subida e 760 metros de descida. Ressalta-se que o deslocamento livre pela área de plantio não está computado nestas medidas, pois elas consistem apenas no trajeto entre os pontos, e duas partes da trilha são percorridas novamente na descida, como é mostrado no mapa abaixo. O circuito foi classificado como de esforço leve e de orientação fácil, segundo o manual da FEMERJ (2015). Para tal, foi feita uma sinalização com baixo grau de intervenção, direcional e confirmatória, em cruzamentos, conforme necessário para a segurança e a orientação dos visitantes (MENEZES, 2013). Também foi complementada a identificação da flora local por placas, que já existiam ao longo da trilha, com 12 placas das espécies mais marcantes de cada área. 


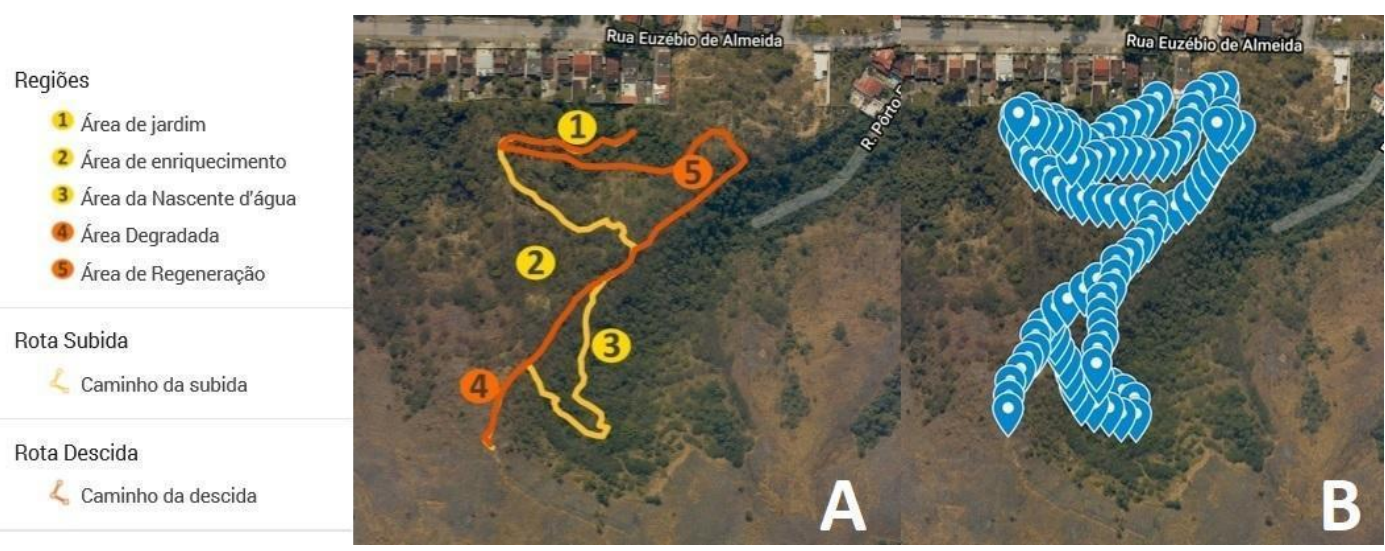

Figura 9: (a) Mapa da trilha geopoética D.O.S.S.E.L.; (b) Mapa da trilha mostrando os 100 pontos de medição das variáveis ambientais pelos robôs " $Q$ ". Fonte: googlemaps.

Figure 9: (a) Map of the geopoetic trail; (b) The trail map showing the 100 measurement points of the environmental variables by the "Q" robots. Source: googlemaps.

Ao longo da trilha era notório esse mosaico de áreas geradas ao longo de 22 anos de reflorestamento voluntário. Numa busca de como intervir no espaço de modo a dar voz a esta história, destacamos a mudança das variáveis ambientais ao longo da trilha como o fio condutor desta teia, na qual foram entrelaçados os demais fios de memórias e conhecimentos atrelados à APAMC. As variáveis ambientais são a forma mais evidente de perceber esta teia invisível, pois nos locais mais reflorestados (com dossel mais completo, sombreado e com maior umidade) temos uma sensação agradável de frescor, enquanto nas partes mais degradadas da trilha (no topo, laterais, clareiras,...) temos uma sensação desagradável de muito calor, pois os locais são "abafados". Além de explorar estas sensações, percebemos que cada trecho conta sua própria história pelas condições do solo, da fauna, da flora e pela presença de objetos oriundos de interferências humanas (como arames farpados, porteiras de fazendas, cacos de louças quebradas, tijolos, caixas d'água, placas de identificação das espécies, entre outros). Estas diferenças das variáveis ambientais foram analisadas por meio da medição de 300 pontos (Figura 9b) e processamento das mesmas por um conjunto de 12 sistemas embarcados, os robôs "Q.", compostos por um arduino nano, sensores ambientais (luminosidade, temperatura do ar e do solo e umidade do ar e do solo), baterias recarregáveis e visor LCD (Figuras 10a, 10b, 10c). As aberturas no solo foram efetuadas no momento da medição, quando os sensores eram enterrados (recobertos com solo) em cada ponto. As medições foram registradas manualmente em tabelas.

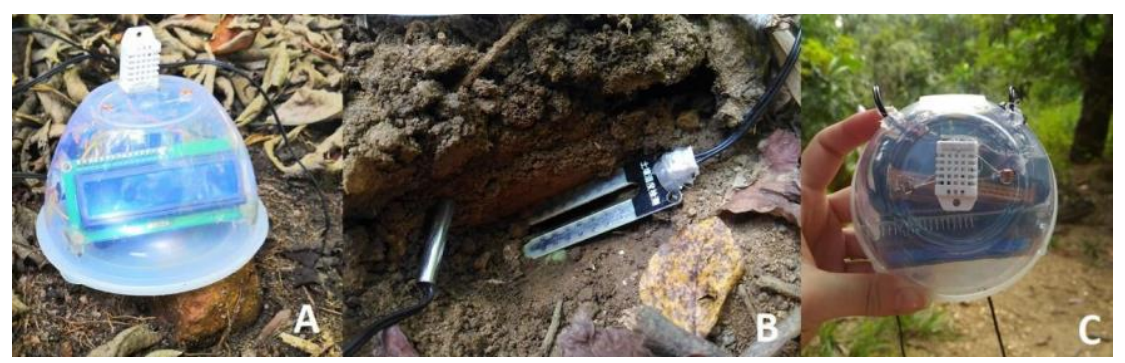

Figura 10: (a) Robô "Q"; (b) sensor de umidade do solo do " $Q$ "; (c) sensor de luminosidade do "Q".

Figure 10: (a) " $Q$ " robot; (b) " $Q$ " soil moisture sensor; (c) " $Q$ " luminosity sensor.

Fonte: fotos de Pedro Santos (2019).

Source: photos by Pedro Santos (2019). 
Estes 300 pontos foram distribuídos de forma que em cada 10 metros foram feitas três medidas, uma no meio do traçado da trilha e outras duas na distância de um metro e meio em cada lateral, para dentro da mata. O intervalo de tempo total de todas as medições foi de uma hora e meia, realizadas concomitantemente por quatro equipes (cada uma com três pessoas, totalizando 12 voluntários de 14 a 53 anos, que participaram das trilhas anteriores) onde cada uma percorreu aproximadamente 250 metros, perfazendo 25 locais e medindo 75 vezes ( 3 vezes em cada local).

Estes dados foram interpretados por uma programação em phyton (linguagem de programação) como a variação das temperaturas (média entre a do ar e do solo), da umidade (média entre a do ar e do solo) e zonas com ausência da luminosidade (pela cobertura do dossel), a fim de destacar um gradiente de interação entre seres humanos e Natureza em fragmentos florestais urbanos, norteando o desenvolvimento dos 13 GeoLiVes. Desta forma, a TEIA DOSSEL abrange toda a trilha, e pode ser mais claramente reconhecida em 13 pontos que entrelaçam os dados associados com cada trecho. Este gradiente das variáveis ambientais determinou o tipo dos fios materiais presentes em cada instalação artística, concretizando a teia e atraindo o olhar do visitante por meio de suas cores e formatos para percorrer as demais partes que compõem este fragmento florestal. O material dos fios varia de acordo com estas medições e a nossa percepção da sensação térmica, de "agradável a desagradável" (trepadeiras secas - juta > sisal fios de crochê > fios de malha e de energia elétrica > arame farpado), demonstrando as variáveis ambientais por um meio visual, com materiais mais "naturais" a fios cada vez mais industrializados (Natureza "mais modificada" pelo ser humano). A luminosidade, diretamente relacionada ao estado das copas das árvores, foi utilizada para determinar a paleta de cores da obra. Nos lugares mais expostos, foram empregadas cores mais vibrantes como o vermelho, amarelo e laranja, e nos locais mais sombreados (com o dossel mais fechado) cores mais terrosas e esverdeadas.

A obra de arte TEIA DOSSEL foi projetada para ser uma experiência integrada e interdisciplinar. Todas estas intervenções são componentes de um sistema maior, projetado para despertar o olhar do visitante quanto aos papéis dos seres humanos neste ambiente reflorestado, numa complexa teia de relações. Cada instalação, atividade de sensibilização e método avaliativo é uma peça dentro do conjunto da sensibilização almejada, gerando um elo afetivo, um sentimento de pertencimento em relação à APA MC, que promove a sua conservação. Deste modo, analisar as instalações artísticas individualmente pode levar a interpretações equivocadas. Apenas quando absorvidas em conjunto elas formam uma narrativa, inspirada no gradiente das variáveis ambientais ao longo da trilha.

Para garantir que os visitantes tivessem esta vivência geopoética com o espaço foram criadas dinâmicas e princípios que nortearam a mediação dos guias com o público. O veículo principal de comunicação não foi a voz do guia e sim a geopoética, com o intuito que a intervenção no espaço cativasse a curiosidade dos visitantes, e a partir de suas percepções foram criados momentos de troca. Desta forma a horizontalidade é um dos pilares desta proposta, onde os saberes científicos, locais e populares têm o mesmo valor, e todos podem contribuir nas conversas que emergem ao longo do caminho. Diferente da trilha guiada, onde por mais que haja troca, a referência do saber e a voz principal é sempre o guia. Outro pilar desta nova abordagem é a interatividade. Todas as instalações são um convite para investigar o espaço, ao tocar e analisar os materiais encontrados na própria 
APAMC (que compõe partes da obra), levando os visitantes a investigarem mais o próprio espaço ao longo da trilha, mesmo sem a presença de uma instalação em todos os locais.

A trilha geopoética da APAMC foi elaborada para receber grupos de visitantes de 15 a 25 pessoas, de todas as idades. Cada grupo foi acompanhado por uma equipe de no mínimo quatro guias (pesquisadores da UNIRIO e UFRJ, junto a moradores, voluntários que foram treinados). Os visitantes puderam explorar a trilha livremente ao longo de seu percurso, desde que não se afastassem dos guias, os quais circulavam entre 0 grupo. Na medida que os visitantes interagiram com o que encontraram ao longo do caminho, os guias conversaram sobre o que estaram vendo. Ou seja, quando os visitantes não interagiam com uma das instalações os guias seguiam a trilha mais atentos, na busca por possíveis gatilhos para dialogar sobre os conhecimentos atrelados com a APAMC, mas não forçavam os visitantes a parar nas instalações.

A proposta de não induzir o comportamento dos visitantes ao longo da atividade foi sendo implementada gradativamente, durante os ensaios. Como o público não estava acostumado com esta metodologia, foi necessário introduzir mais dinâmicas de sensibilização na abertura da atividade, como exercícios para potencializar momentos de investigação livre. Foram elaboradas três dinâmicas de sensibilização: (1) articulando os sentidos (momento de recepção dos visitantes), (2) o plantio de mudas nativas de Mata Atlântica e (3) o lanche solidário. Além destas, para analisar a vivência como um todo, foram integrados três métodos avaliativos: o questionário anônimo de amostras pareadas por indivíduo, com uma parte sendo preenchida antes de iniciar a atividade (quanto às expectativas) e outra parte no final, sobre a avaliação; uma roda de conversa e a filmagem na íntegra da atividade, por meio de 3 câmeras que estavam acopladas na roupa na frente dos guias.

A costura entre todas essas partes com a proposta de sensibilização realizada nas instalações ao longo da trilha pode ser resumida da seguinte forma: no início, os visitantes são recebidos na "sede" (casa de um morador com um portão nos fundos que dá acesso à trilha) pelos guias, onde é explicado o caráter de pesquisa atrelado com a atividade e é aplicada a primeira parte do questionário anônimo. Os visitantes recebem um caderno de resposta (folha A4 dobrada) e o cabeçalho do questionário com seis perguntas sobre a sua expectativa. Este caderno permanece com os visitantes ao longo de toda a atividade, onde eles podem acrescentar suas observações durante a atividade. No final é entregue o segundo cabeçalho do questionário, com cinco perguntas avaliando a atividade. Todas as perguntas são discursivas.

Com todos os componentes do grupo presentes, iniciamos atividade com uma dinâmica de sensibilização em roda, chamada de articulando os sentidos, onde a proposta é que cada visitante seja um componente desta intervenção na APAMC. A interação entre os visitantes, guias, voluntários, fauna, flora, geodiversidade, serviços ecossistêmicos culturais, dentre outros, é determinante para construir a trilha. Ainda que o caminho físico seja o mesmo, as dimensões dos saberes sobre ela são atravessadas a partir das percepções compartilhadas pelos visitantes.

Esta atividade de sensibilização inicia com um vídeo que cativa a curiosidade dos visitantes sobre o que será vivenciado ao longo do evento, depois seguimos para a apresentação da equipe e uma conversa sobre as recomendações de segurança ao longo da trilha. Os visitantes são então convidados para o jardim desta 
casa, onde encontram uma roda demarcada por mudas nativas de Mata Atlântica (as que serão plantadas pelo grupo) em volta de uma mesa com um mapa da trilha (feito de papel reciclado e terra coletada nas cinco áreas da trilha, com o trajeto demarcado por pimenta rosa), objetos para serem usados como focos de visão (lentes, lupas, binóculos, câmeras antigas, óculos, trepadeiras em formato de lentes e óculos, pedaços de troncos com orifícios) e papel terra (papel reciclado misturado com terra). O grupo forma uma roda junto das mudas, e os focos de visão são distribuídos para exercitarmos novas perspectivas de formas de enxergar a Natureza, enquanto é proposto um alongamento. Dando prosseguimento, os visitantes se apresentam pelo seu nome, idade, uma representação sobre como estão se sentindo naquele instante, escolhendo um elemento da Natureza (elementos da biodiversidade, geodiversidade ou fenômenos naturais), e comentários sobre se já fizeram trilhas ou plantaram árvores antes. Na medida em que uma das guias entrega o fio de malha para o visitante segurar, este se apresenta e continua segurando o fio, o qual percorre todos os visitantes, formando uma teia (Figura 11a). Neste fio estão escritos poemas do repertório geopoético do grupo Geotales - UNIRIO. Uma vez que todos se apresentaram, os visitantes são direcionados para iniciar a trilha, ajudando no transporte das mudas e de bolsas de água para regá-las.

Um dos componentes da equipe que acompanha o grupo ao longo da atividade, apresentado durante esta dinâmica de sensibilização, é o robô Quemuda. Ele é um sistema embarcado, assim como os robôs "Q", mas além de um arduino nano, sensores ambientais (umidade do ar e do solo, temperatura do ar e do solo e luminosidade) e visor LCD ele também é composto por um raspberry, memória SD, bateria solar recarregável e três câmeras de $180^{\circ}$ conectadas por wi-fi, que estão acopladas a cintos peitorais que são utilizados por três guias ao longo da trilha (Figura 11b). O raspberry emite uma rede de wi-fi local, sem internet, apenas uma conexão via rede entre os eletrônicos que se conectarem a ela, intitulada DOSSEL. Estas câmeras gravam toda a atividade, para análise posterior.

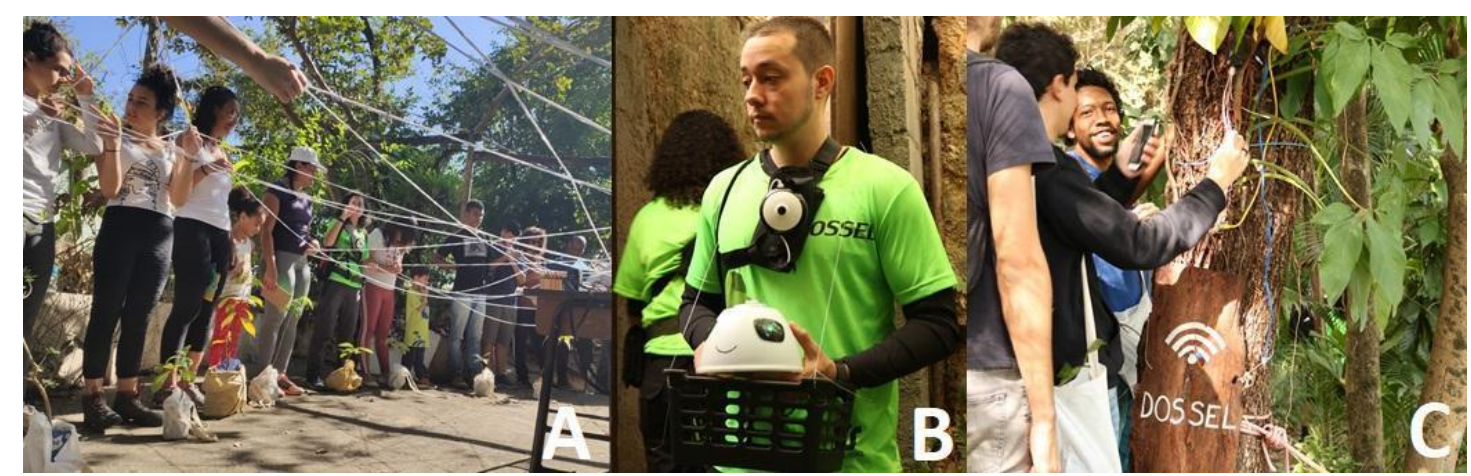

Figura 11: (a) Construindo a teia durante a dinâmica da sensibilização "articulando os sentidos"; (b) Robô Quemuda; (c) uma das instalações artísticas na trilha, com o sinal de wi-fi DOSSEL.

Figure 11: (a) Constructing the web during the dynamics of sensitization, "articulating the senses";

(b) Robot Quemuda (Who changes); (c) one of the artistic installations on the trail with the wi-fi DOSSEL signal.

Fonte: fotos de Valéria Neves (2019).

Source: photos by Valéria Neves (2019). 
Os visitantes, por meio de seus celulares, podem se conectar a esta rede wi-fi e acessar a imagem e voz ao vivo das três câmeras pelo aplicativo ICSEE. No entanto, os visitantes têm que iniciar um diálogo sobre os robôs para que os guias expliquem como funcionam as câmeras. Os doze robôs " $Q$ " foram dispostos ao longo do jardim e no início da trilha, com placas com a frase "Veja como nós" e com o passo a passo para baixar o aplicativo no celular e acessar as câmeras. Além disso, o símbolo do wi-fi junto à palavra "dossel" está em diversos materiais dispostos nestes espaços (Figura 11c). No momento que o primeiro visitante acessa a câmera, ele mesmo cativa os demais a tentarem. As câmeras dispostas no peitoral dos guias possibilitam que os guias mostrem detalhes que passaram desapercebidos aos visitantes, para que eles então procurem com os próprios olhos. Desta forma, as câmeras são mais uma perspectiva para olhar para a APAMC estimulando os visitantes a explorarem o espaço.

O Quemuda também tenta despertar a percepção sensível dos visitantes quanto às mudanças das variáveis ambientais ao longo da trilha. Este sistema embarcado mede as variáveis ambientais durante a trilha e interpreta como está o ambiente naquele dia, comparando-as com medições prévias da trilha, feitas pelos robôs "Q". Esta análise do ambiente é comunicada aos visitantes pela cor de seus "olhos", formados por dois led's RGB, onde a cor é a mistura de três domínios: o "R"red- vermelho foi codificado com a variação das temperaturas (média entre o do ar e do solo), o "G" - green- verde com a ausência da luminosidade e o "B" - blue - azul com a umidade (média entre o do ar e do solo), sendo uma representação em cores do próprio gradiente de interação entre seres humanos e Natureza, que norteou a elaboração de toda a proposta.

Iniciando a caminhada, o percurso utilizado na trilha é uma subida até o mirante, perpassando a área das nascentes d'água - porção mais úmida e o "coração" da obra - até chegar no topo da área reflorestada, numa região degradada que apresenta uma vegetação de gramíneas, seguindo com a descida por outro caminho, até retornar ao ponto inicial (casa "sede").

As instalações iniciam com formatos mais tradicionais e discretos, instigando aos poucos a curiosidade dos visitantes, pela estranheza de encontrá-las no meio de uma trilha (Figura 12a, 12b). Em todas elas há poemas que falam sobre o tema da instalação, dispostos também de forma discreta e até escondida. Com os olhares mais atentos, as instalações se aprofundam cada vez mais nas questões históricas, interferências antrópicas positivas e negativas, considerando a constituição biótica e abiótica de cada trecho deste mosaico reflorestado. No meio da trilha o local das instalações se torna menos evidente, e apenas quem procura com mais atenção consegue encontrá-las. Chegando na área das nascentes (Figura 12c), a brisa nos abraça e conforta, o ritmo da caminhada diminui e o olhar se direciona para cada elemento da Natureza que encontramos no local, compondo a teia da vida na qual o ser humano está envolvido. 


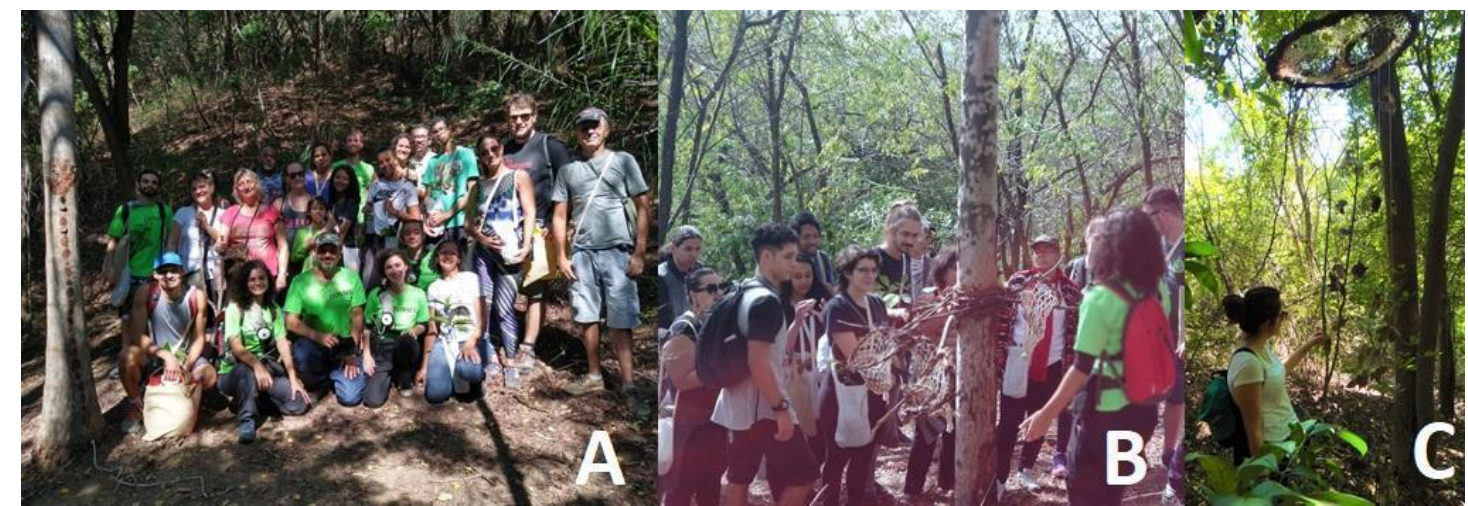

Figura 12: (a) Grupo de visitantes ao lado de uma das instalações artísticas na palmeira ao lado (b) visitantes explorando uma das instalações artísticas na área de enriquecimento; (c) visitante explorando uma das instalações artísticas na área das nascentes d'água.

Figure 12: (a) group of visitors at the side of one of the art installations on the palm tree; (b) visitors exploring one of the art installations in the enrichment area; (c) visitor exploring one of the artistic installations in the water source area.

Fonte: fotos de Valéria Neves (2019).

Source: photos by Valéria Neves (2019).

Seguindo o percurso da trilha adentramos a porção mais degradada, gerando uma sensação de quem passou por um "portal de calor" em poucos metros. A falta do dossel é bruscamente percebida e o diálogo se volta para os fatores de degradação e a ausência da fauna, problematizando as florestas vazias (REDFORD, 1992). Dentre os fatores de degradação destacamos as queimadas, que tem acontecido anualmente no mês de junho pela queda de balões em chamas (na Figura 13a vemos a instalação artística que aborda a questão das queimadas).

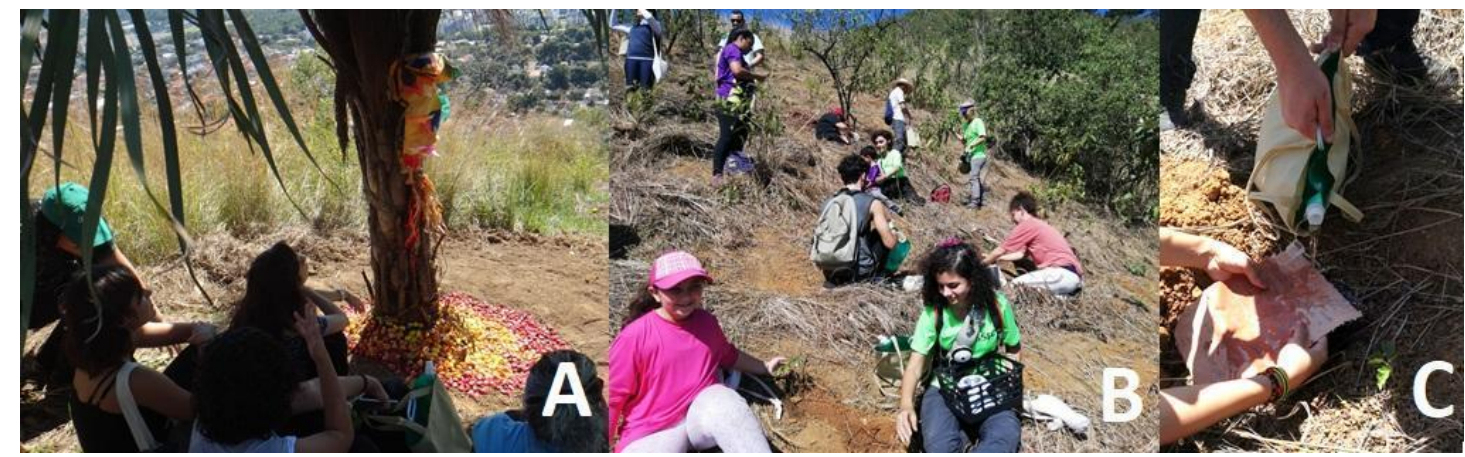

Figura 13: (a) visitantes explorando uma das instalações artísticas na área degradada; (b) visitantes plantando as mudas; (c) visitantes plantando com o papel semente.

Figure 13: (a) visitors exploring one of the artistic facilities in the degraded area; (b) visitors planting the seedlings; (c) visitors planting with the recycled seed paper.

Fonte: fotos de Valéria Neves (2019).

Source: photos by Valéria Neves (2019).

No limite entre a área reflorestada e a degradada é feito o plantio de mudas nativas de Mata Atlântica (Figura 13b) e a apreciação do mirante, que possibilita, em dias de boa visibilidade, avistar grande parte da Zona Oeste do Rio de Janeiro, a Serra do Mendanha, a Serra dos Órgãos e a ponta da Baía de Guanabara. À direita vemos a ponta do Parque Nacional da Tijuca e o complexo do Alemão, reconhecido por seu teleférico, e ainda que não possa ser visto, atrás dali está o Parque Estadual 
da Pedra Branca, com a APAMC fazendo parte de sua zona de amortecimento. Associada ao plantio das mudas ocorre a segunda dinâmica de sensibilização, com a escrita das cartas em papel terra (papel reciclado com $30 \%$ de terra adicionada na polpa), quando os visitantes escrevem ou desenham mensagens pra as suas mudas, adubando as plantas com palavras de afeto (Figura 13c). Essas cartas podem ser amassadas ou cortadas em pedaços, encharcadas com água e dispostas nos berços (buracos previamente preparados para receber as mudas) antes do transplante da muda. Os guias auxiliam os visitantes nesta dinâmica. Algumas pessoas preferem levar as cartas para casa, ou deixar em cima do solo.

O grupo procede retornando ao ponto de partida por um caminho diferente da subida. Adentramos na área reflorestada por uma descida íngreme como uma escada, coberta por um túnel que foi formado pela copa das árvores Sábias (espécies exóticas, que foram introduzidas no início do reflorestamento). As instalações neste trecho provocam a diminuição do ritmo da caminhada, estando em locais inusitados como pedras e galhos secos no chão. Em um dado ponto uma das instalações "fecha" o caminho, e para continuar na trilha é necessário interagir fisicamente com ela (Figura 14a). Após este "obstáculo" o percurso se torna menos íngreme e as instalações se tornam novamente mais veladas, até chegar a um trecho em que percorremos a primeira trilha aberta no reflorestamento, que não era mais utilizada. Neste local há uma grande quantidade de espécies exóticas, e como os voluntários do reflorestamento não circulavam por esta porção ocorreu uma regeneração natural da flora, com muitos exemplares da mesma espécie adensados. Uma delas se destaca, a Agave verde gigante, que ajuda a redimensionar o tamanho a espécie humana, perante o seu porte. No último trecho o caminho de retorno volta ao mesmo do início da trilha, já conhecido, porém esperase que a sensibilização do olhar o torne diferente, percebendo o espaço de outra forma, mais vivo, dinâmico e complexo, onde a espécie humana constitui apenas mais um dos componentes desta teia.

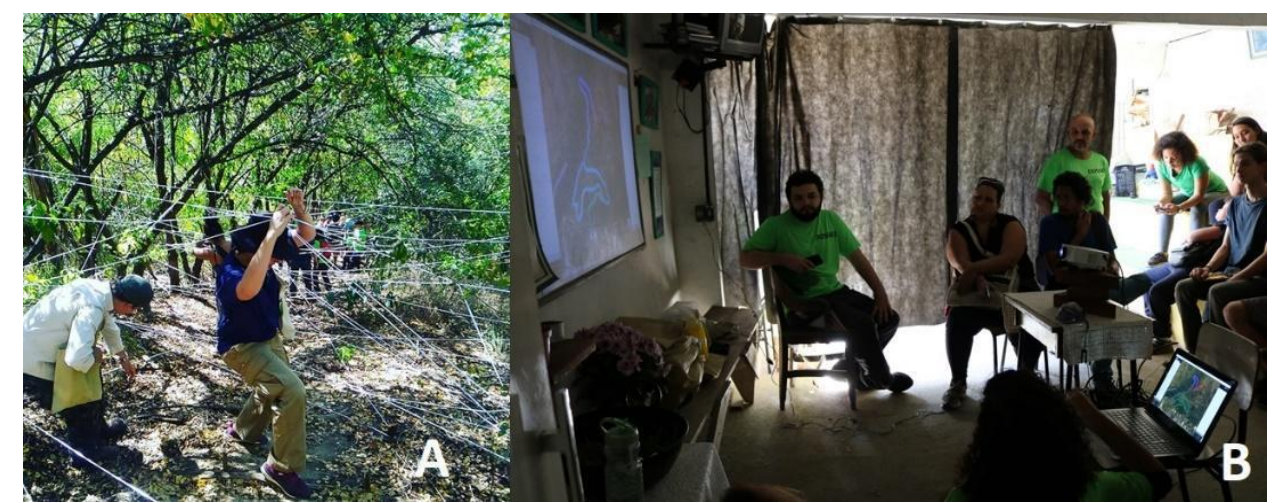

Figura 14: (a) Visitantes percorrendo a instalação artística que bloqueia o caminho da descida;

(b) visitantes assistindo à projeção da animação do gradiente de cor ao longo da trilha.

Figure 14: (a) Visitors walking through the artistic installation that blocks the path of return; (b_ visitors watching the projection of color gradient animation along the track.

Fonte: fotos de Valéria Neves (2019).

Source: photos by Valéria Neves (2019).

Retornando para a "sede" os visitantes são recebidos por uma mesa composta pelos lanches que eles e os guias trouxeram. O lanche solidário é divulgado na confirmação de inscrição dos visitantes. A contribuição dos guias é 
com frutas, doces caseiros de frutas, sucos e chás feitos com alimentos colhidos na própria área reflorestada da APAMC.

Neste momento de compartilhar, iniciando pelas comidas, seguimos para o compartilhamento de opiniões e percepções na roda de conversa. O primeiro a expor sua perspectiva da trilha é o robô Quemuda, por meio de uma projeção pelo software Processing de um gradiente de cores sobreposto ao mapa da trilha percorrida (Figura 14b). Em cinco pontos ao longo da trilha (um em cada área da Figura) foram medidas as variáveis ambientais do solo, enquanto as do ar e a luminosidade foram medidas ininterruptamente, em cada dia de realização da trilha com os visitantes. Estas cinco medidas são comparadas entre si, e seguem o mesmo código da variação dos olhos do Quemuda ao longo da trilha. A cor é formada por uma programação de RGB, onde as maiores medições de temperaturas (média entre ar e solo) são atreladas ao domínio vermelho, as menores medições de luminosidade ao verde, e as maiores medições de umidade (média entre ar e solo) ao azul. Com esta projeção iniciamos um diálogo para associar o que foi vivenciado com o mapa, e seguimos para acolher as falas dos visitantes que queiram compartilhar suas percepções. Fechando a atividade são distribuídos os cabeçalhos com as perguntas de avaliação da trilha geopoética, respondidas no mesmo caderno resposta que foi entregue no início da atividade. Eles são recebidos anonimamente, por meio de uma caixa de respostas, onde são depositados pelos visitantes.

\section{Considerações finais}

A APAMC tem um grande potencial ainda latente, tendo sido aqui destacadas diversas possibilidades de atividades ecoturísticas, educacionais e culturais que podem ser desenvolvidas neste local. No caminho que construímos junto aos moradores do JS, muitas vozes ecoaram nas diversas camadas de fios que formam esta teia de relações entre o bairro e a APAMC. Neste emaranhado de sentidos, a partir de percepções individuais e coletivas, concluímos que a falta de novas vivências no local (que sedimentou muitas memórias afetivas nas gerações mais antigas), distanciou os moradores do JS da APAMC. Este ambiente, que antigamente era como uma continuação dos quintais além dos muros das casas passou a ser visto como um bloco verde, estático, preexistente e perigoso, pela sensação de insegurança relacionada a todos os morros do Rio de Janeiro.

Por meio de uma (re)significação destas impressões dos moradores do JS sobre a APAMC, este trabalho começou um processo que visa despertar novos olhares mais sensíveis, ecológicos e lúdicos, fortalecendo os fios que sustentam as iniciativas de ecoturismo e conservação que existem em todo o bairro. Vista por dentro, numa visão mais ampla e integrada, percebe-se a importância de fortalecer igualmente todos os fios da teia, que partem em várias direções, não só na trilha Geopoética, mas também em todas as dimensões materiais e imateriais do bairro, unificando ser humano, Natureza, Arte e Tecnologia por meio da tessitura das vozes geopoéticas. As instalações artísticas - GeoLiVes - são as flores que desabrocharam nos galhos ao longo da trilha, manifestando materialmente a presença da teia da vida. 


\section{Referências}

BALDISSERA, A. Pesquisa-ação: uma metodologia do "conhecer" e do "agir" coletivo. Sociedade em Debate, Pelotas, v. 7, n. 2, p. 5-25, ago. 2001.

BOUVET, R. Como habitar o mundo de maneira geopoética? Interfaces Brasil/Canadá, 2012. v. 12. Disponível em: nhttp://www.revistas.unilasalle.edu.br/ index.php/interfaces/issue/view/50, acessado em 20/12/2017.

EMBRATUR. Instituto Brasileiro de Turismo. Diretrizes para uma política nacional de ecoturismo. Brasília, DF: MICT/MMA, 1994.

FEMERJ. Metodologia de classificação de trilhas. 2015, v.6, n.1.

GLISSMAN, P.; HÖFFLIN, M. ELF-electronic life forms. In: ACM SIGGRAPH 2005 Electronic Art and Animation Catalog. ACM, 2005. p. 70-71.

INEA - Instituto Estadual Ambiental. Plano de Manejo do Parque Estadual da Pedra Branca. Rio de Janeiro: INEA, 2013.

INSTITUTO BRASILEIRO DE GEOGRAFIA E ESTATÍSTICA - IBGE. Síntese de indicadores sociais: Uma análise das condições de vida da população brasileira 2010. Rio de Janeiro: IBGE, 2010. (Estudos e Pesquisas: Informação Demográfica e Socioeconômica, n. 27).

HAMDAN, C. Corpos Tatuados: Experiências Sensíveis em Realidade Aumentada Móvel. 2015 Tese (Doutorado) - Programa de Pós-Graduação em Arte - PPGArte, Universidade de Brasília, 2015. 344 p.

INSTITUTO ESTADUAL AMBIENTAL (INEA). Plano de Manejo do Parque Estadual da Pedra Branca. Rio de Janeiro: INEA, 2013.

INSTITUTO BRASILEIRO DE GEOGRAFIA E ESTATÍSTICA - IBGE. Síntese de indicadores sociais: uma análise das condições de vida da população brasileira 2010. Rio de Janeiro: IBGE, 2010. (Estudos e Pesquisas: Informação Demográfica e Socioeconômica, n. 27).

KRUSE, L. Compréhension de l'environnement dans la psychologie de l'environnement. São Paulo: Psicologia USP, 2005. V.16, p. 41-46.

LAILACH, M. Land Art. Colónia: TASCHEN, 2007.

NÓBREGA, C. A.; FRAGOSO, M. L.Pode um sistema telemático prover uma experiência em arte? Arte, ciência e tecnologia nas experimentações artísticas do laboratório NANO. Revista Eletrônica MAPA D2 - Mapa e Programa de Artes em Dança (e performance) Digital, Ivani Santana (Org) Salvador: PPGAC, 2015; v.2, n.2, p.53-166.

MINISTÉRIO DA AGRICULTURA, PECUÁRIA E ABASTECIMENTO. Bancos comunitários de sementes de adubos verdes: cartilha para agricultores. Brasília: MAPA, 2007.

MILLENNIUM ECOSYSTEM ASSESSMENT (MEA). In: Ecosystems and human well-being: biodiversity synthesis. Washington, DC: World Resources Institute, 2005.

MENEZES, P. C. Sinalização de trilhas - Guia Prático. Edição digital, Rio de Janeiro, 2013. 
MINAYO, M. C. S. Introdução. In: MINAYO, M. C. S.; ASSIS, S. G.; SOUZA, E. R. (Org.). Avaliação por triangulação de métodos: Abordagem de Programas Sociais. Rio de Janeiro: Fiocruz, pp. 19-51, 2010.

PONCIANO, L.C.M.O. Geomitologia: Era uma vez... na história da Terra. Belém: Revista Sentidos da Cultura, 2015. V. 2, n. 2, $22-42$ p.

PONCIANO, L.C.M.O. 2018. Geotales: narrando as histórias petrificadas pela Terra. Belém: Revista Sentidos da Cultura, 2018. n.5, $34-48$ p.

PRIMACK, R. B.; RODRIGUES, E. Biologia da Conservação. Londrina: Efraim Rodrigues, p. 200-234. 2001

RIO DE JANEIRO. Lei no 4659/2007. Dispõe sobre a área de proteção ambiental do Morro do Cachambi e de outras providências. Diário Oficial do Município do Rio de Janeiro, Ano XXI, №144, p. 10, 2007.

REDFORD, K. H.The Empty Forest. BioScience, 1992. V. 42, n. 6, 412-422 p. Disponível em: <http://www.jstor.org/stable/1311860 >. Acesso em 10.08. 2017

SANTOS, C. J. F.; FONTES, A. M.; SOUZA, M. H. Projeto mutirão: uma alternativa para o reflorestamento de encostas de risco em região de baixa renda. Rio de Janeiro: PMRJ/SMAC, 1987.

SANTOS, L.B.M.; HÖRMANSEDER, B.M.; SANTOS, L.F.; ARAUJO, D.O.; LOPES, M. L.O. C.; LEME, G. F. P.; PONCIANO, L. C. M. O.Paleontologia cultural: uma análise sobre fósseis e monstros da Amazônia - O Mapinguari. In: I COLÓQUIO DE ZOOLOGIA CULTURAL, 2016, Rio de Janeiro. - Livro do Evento Rio de Janeiro: Perse, 2016, p. 114 - 129. ISBN 978-85-464-0413-1.

SANTOS, L. B. M. GeoTales: A divulgação das Geociências atravessada pela poética das vozes da Terra. 2017. Monografia (Graduação - Bacharelado em Ciências Biológicas) - Instituto de Biociências, Universidade Federal do Estado do Rio de Janeiro - RJ.

SANTOS, L. B. M.; PONCIANO, L. C. M. Interfaces entre ecoturismo e educação na APA do Morro do Cachambi, Jardim Sulacap, RJ. In: OLIVEIRA, M. A. S. A. O. Espaços sociais de formação educativa: turismo, escola, casa e cidade. 1ed. Rio de Janeiro: Lamparina (No prelo), 2019, v. 1.

SMMA. Parques Carioca. Corredor Verde. Rio de Janeiro: Secretaria Municipal do Meio Ambiente, 2015.

THIOLLENT, M. Metodologia da pesquisa-ação. São Paulo: Cortez, 16ed., 2008.

TUAN, Y. Topofilia, um estudo da percepção, altitudes e valores de meio ambiente. São Paulo: Difel, 1980.

UEXKÜLL J. von 1921. Umwelt und Innenwelt der Tiere. 2. verm. u. verb. Aufl. Berlin: J. Springer, 224.

UNESCO. Convenção para a proteção do patrimônio mundial natural e cultural. 1972. Disponível em: <whc.unesco.org>. Acesso em 10.02. 2017.

WEARING, S.; NEIL, J. Ecoturismo: Impactos, Potencialidades e Possibilidades. São Paulo: Manole, 2014,1-17 p.

WHITE, K. La Plateau de l'Albatros : Introduction a La Geopoetique. Paris: Grasset et Fasquelle, 1998. 
WHITE, K. panorama géopoétique. Théorie d'une textonique de la terre. Paris: Editions de la Revue des Ressources, 2014.

Nota: Estes resultados fazem parte da pesquisa intitulada "D.O.SS.E.L. Jardim Sulacap: Despertando Olhares Sensíveis Sustentáveis Ecológicos e Lúdicos.", vinculada ao Mestrado Profissional em Ecoturismo e Conservação (PPGEC UNIRIO), em parceria com o Núcleo de Arte e Novos Organismos - NANO/ UFRJ, coordenado pelo Dr. Carlos Augusto Moreira da Nóbrega. Além da participação dos pesquisadores voluntários Pedro Santos (graduando em Engenharia de Controle e Automação da UFRJ) e Leandro Pinheiro (Bacharel e licenciado em Educação Física).

Lilaz Beatriz Monteiro Santos: Universidade Federal do Estado do Rio de Janeiro, Rio de Janeiro, RJ, Brasil

E-mail: lilaz.santos@edu.unirio.br

Link para o currículo Lattes: http://lattes.cnpq.br/3730875542401159

Bruno Francisco Teixeira Simões: Universidade Federal do Rio de Janeiro, Rio de Janeiro, RJ, Brasil

E-mail: bruno.simoes@uniriotec.br

Link para o currículo Lattes: http://lattes.cnpq.br/0985291000032685

Luiza Corral Martins de Oliveira Ponciano: Universidade Federal do Estado do Rio de Janeiro, Rio de Janeiro, RJ, Brasil

E-mail: luiza.ponciano@unirio.com

Link para o currículo Lattes: http://lattes.cnpq.br/0519721250469036

Data de submissão: 25 de março de 2019

Data de recebimento de correções: 24 de junho de 2019

Data do aceite: 24 de junho de 2019

Avaliado anonimamente 